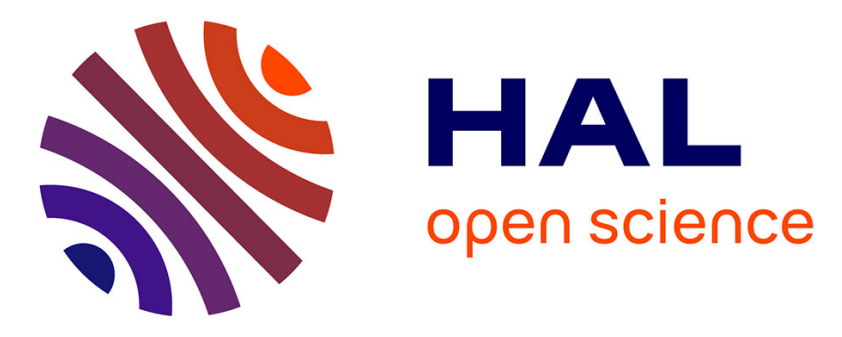

\title{
Spatial Mobility and Access to Resources among the African Pygmies
}

\author{
Serge Bahuchet
}

\section{To cite this version:}

Serge Bahuchet. Spatial Mobility and Access to Resources among the African Pygmies. Michael J. Casimir, Aparna Rao. Mobility and Territoriality: Social and Spatial Boundaries among Foragers, Fishers, Pastoralists and Peripatetics, Berg Publ. (NY, Oxford), pp.205-255, 1991. hal-00261573

\section{HAL Id: hal-00261573 https://hal.science/hal-00261573}

Submitted on 7 Mar 2008

HAL is a multi-disciplinary open access archive for the deposit and dissemination of scientific research documents, whether they are published or not. The documents may come from teaching and research institutions in France or abroad, or from public or private research centers.
L'archive ouverte pluridisciplinaire HAL, est destinée au dépôt et à la diffusion de documents scientifiques de niveau recherche, publiés ou non, émanant des établissements d'enseignement et de recherche français ou étrangers, des laboratoires publics ou privés. 
In: CASIMIR (M.J.)\& A.RAo,eds, 1991.Nobitif and tenitinalizs sovial and

\title{
Spatial Mobility and Access \\ to Resources among the African Pygmies
}

\author{
Serge Bahuchet
}

\section{Introduction}

African Pygmies have occupied a prominent place in the debate about mobility and territoriality among hunters and gatherers, being one of the two examples used by Tiirnbull to define the notion of flux (1968). It is well known by now that arnong hunting and gathering societies, the problem of the determination of territoriality is linked with the definition of both group structure and spatial mobility (cf. Lee 1972). We cannot forget, however, that the emergence of territoriality is sometimes assumed to be connected with agriculture, with sedentarity, or with trade (as the fur-trade in the case of subarctic North American Indians, Leacock 1954). African Pygmies, as a mobile but only semi-nomadic population, also provide us with the example of a hunting and gathenng society strongly linked with agricultural people; we have then to examine the consequences of these relations for the territorial behaviour of the Pygmies.

In this paper I wili present data concerning the three major Pygmy groups of Central Africa: the Mbuti Pygmies of eastern Zairre, the Aka of the Central African Republic, whom I studied for several years (Bahuchet 1985) and the Baka of eastern Cameroon, who show many similarities with the Aka although they speak a different language. Before comparing various foraging groups living in very different ecosystems (cf. Kelly 1983), it seems useful to compare populations living in the same environment, the equatorial rain forest, in order to underline similarities, if any. This may help 
in the evaluation of the respective weightage of ecological and social constraints. It seems likely that, in the case of the Pygmies, the history of the relationship with non-Pygmy populations, a human factor which is not taken into account by current theories on optimal foraging strategies (cf. Winterhalder and Smith 1981), has had more influence on the use of space than the resources. We will also examine what kind of social mechanisms, such as cooperation and mutual aid, accompany territorial behaviour and eventually result in the minimisation of territoriality.

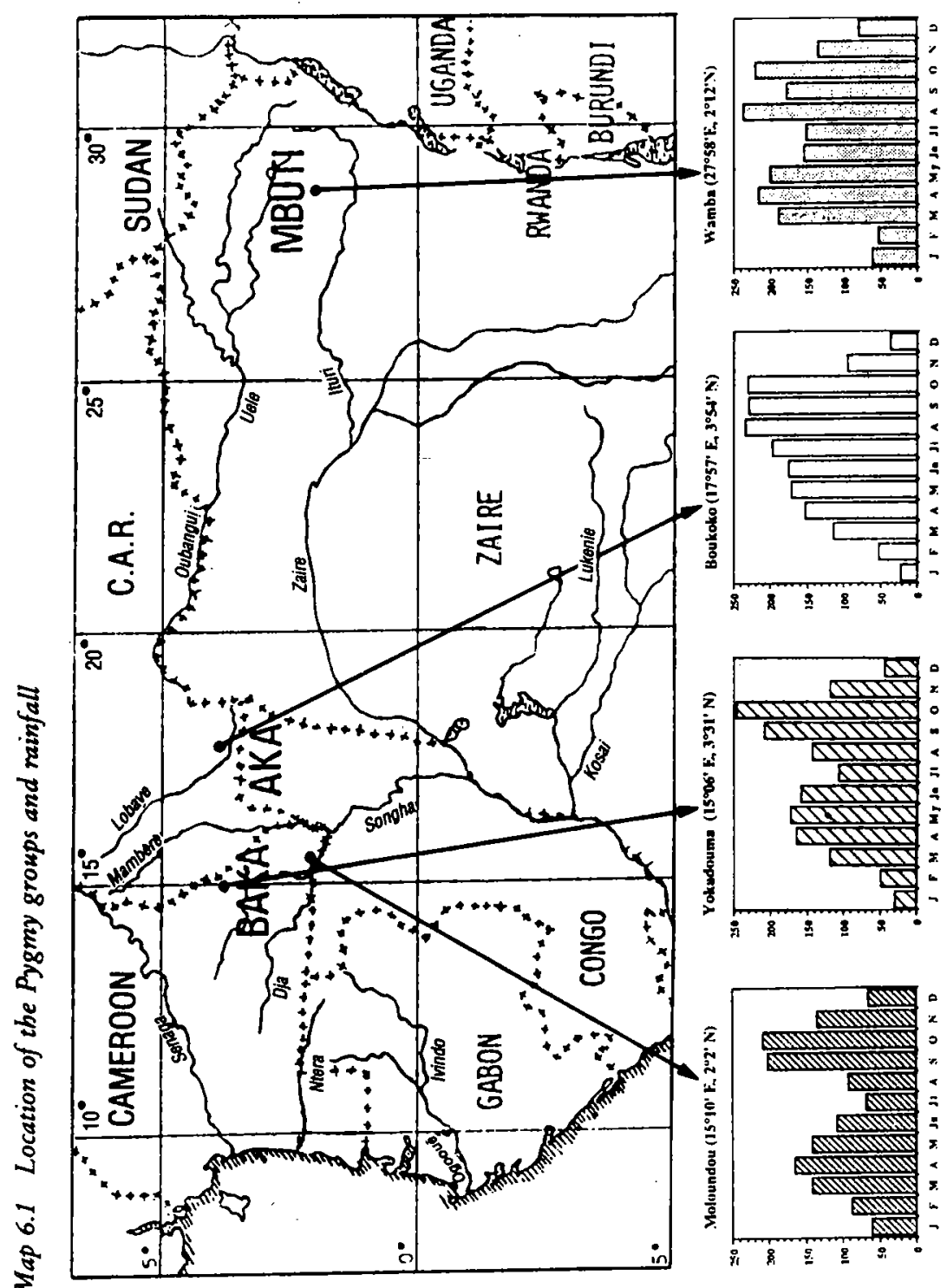

\section{Spatial Distribution of Resources in the Equatorial Rain Forest}

Food resources availability varies according to space and time, thus influencing human spatial mobility. However, the access to food resources depends on the possible movements and characteristics of the combined ranging patterns of the individuals and of the group.

Unlike most terrestrial ecosystems, the rain forest is characterised by a very high number of living species, each of them represented by a small number of individuals. Harris (1969) proposed to call it a 'generalised ecosystem', as opposed to a 'specialised ecosystem' such as the tundra. A generalised ecosystem is characterised by a great variety of species, each of which is represented by a relatively small number of individuals. On the contrary, in a specialised ecosystem there is a small variety of species, represented by a large number of individual organisms. In relation to species-richness, there is a lesser density of individuals in a generalised ecosystem. One hectare of rain forest includes about 100 species of trees; this is the total number of species present throughout the whole European forest.

The typical feature of the rain forest is its structural beterogeneity, which can be found at the local as well as the regional levels. ${ }^{1}$ It is due to the spatial distribution of plant species which depends on various patterns of regeneration. Any tree fall opens a break in the canopy. This gap allows the light to reach the ground level, thus allowing the growth of juvenile trees and lianas in the undergrowth. Because of this regeneration process, the forest is actually a mosaic, constituted by the juxtaposition of micro-milieux, in different growing phases, and at the same time of various sizes, floristic composition and lifetime (Hladik 1982: 388). Thus, only 5-10 per cent of a large area consists of small patches at the final stage of fully 
mature forest growth (Oldeman 1974, Hallé et al. 1978; cf. also Hladik 1978, 1981, Bahuchet 1978). In the same way the animal species which use this mosaic structure differently, depending on their choice of sleeping and feeding sites, also present a patchy distribution.

Several types of forests can be observed at a larger scale, according to local soil composition and microclimates. For instance, both the flora and the fauna of swampy forests differ from those of dry land forests. Large mammals, such as the elephant and situtunga (Tragelaphus spekei) which are preferred game for the Aka, inhabit the swampy ecosystem. The red hog (Potamochoerus porcus) prefers the deciduous forest, while other antelopes like the bongo (Boocercus euryceros) live preferentially in the evergreen forest. In the same way, many tree species such as the Entandrophragma species (Meliaceae), depleted by edible caterpillars, seem to grow preferentially on some types of ferallitic soils.

This structural heterogeneity has to be taken into consideration while comparing various groups of Pygmies, like Mbuti and Aka. The whole Congo basin is covered by various types of rain forests, swampy or not, according to the hydrometrical characteristics (evergreen or semideciduous rain forests), with different dominant species (cf. White 1983, Letouzey 1985). I was able to show that eight different kinds of forests grow on the various parts of the Aka country between $2^{\circ}$ and $4^{\circ} \mathrm{N}$ (Bahuchet 1978: 278-83), and Harako (1976: 41) observed three types of forests in the Ituri region, where the Mbuti Pygmies live (see Map 6.1).

There are some current debates about the possibility of a hunting and gathering way of life in the rain forest without agriculture (cf. Bailey and Peacock 1988, Headland 1987) but the only ecological account of the availability of resources (Hart and Hart 1986) is mainly concerned with the very peculiar Gilbertiodendron monospecific forest, rather than a so-called 'primary forest'. in general.

The variable patterns of spatial distribution of trees and lianas of the rain forest result in different distances between individuals of the various plant species producing fruits or other types of foodstuffs. Biomass of resources is an important factor, as well as dispersion of individuals.

Several authors have tried to formalise the characteristics of resources for purposes of modelisation. Bicchieri (1969), for instance, opposed a permissive environment with abundant and concentrated resources, to a restrictive environment with scarce and
Table 6.1 Types of food resources in the rain forest

\begin{tabular}{|c|l|l|}
\hline \multirow{5}{*}{ fixed } & \multicolumn{1}{|c|}{ dispersed } & \multicolumn{1}{c|}{ concentrated } \\
\hline trees (Anonidium mannii, \\
$\begin{array}{l}\text { Panda oleosa); lianas } \\
\text { (Gnetum spec.); yams } \\
\text { (Dioscreaceae); } \\
\text { several honey trees }\end{array}$ & $\begin{array}{l}\text { tree (Gilbertiodendron dewevrei) } \\
\text { yam (Dioscorea minutiflora); } \\
\text { mushrooms (Termitomyces); } \\
\text { caterpillar; producing tree of } \\
\text { Irvingia spec. }\end{array}$ \\
\hline $\begin{array}{l}\text { duikers, tree hyrax, } \\
\text { monkey (Cercopithecus } \\
\text { neglectus) }\end{array}$ & $\begin{array}{l}\text { troops: monkeys; } \\
\text { herds: hogs, elephants }\end{array}$ \\
\hline
\end{tabular}

dispersed resources, adding the distinction between fixed (those of gathering) and mobile (the hunted animals) resources. Wilmsen (1973) uses an ethological model built by Horn for the blackbirds, in which he distinguishes between stable food resources which are predictable, and uncertain mobile food resources. Wilmsen (1973: 9) pointed out that some animals may be included in the stable category, such as small burrowing species or solitary cervids which spend their entire life within small areas.

In the rain forest ecosystem we can also distinguish between fixed and mobile food resources (see Table 6.1). In both cases, they can be either dispersed or concentrated. Mobile resources are the game, some of them living in herds (hogs, elephants) or troops (guenons), others being isolated or in couples (e.g. duikers, tree hyrax or Brazza's monkey). The mobility of the game is, to some extent, predicted by the hunters: with their knowledge of the habits and behaviour of the animal species they may visit the places where the animals feed or sleep, for instance the fruiting trees or the dense thickets.

Fixed resources include both plants and some invertebrates living upon plants, like caterpillars feeding on the leaves or honey bees feeding on the flowers. According to the heterogeneity factor we described before, a large majority of the plant species are dispersed, counting one or very few individuals by square unit. The vines such as Gnetum (the leaves of which are an important food resource), most yam species Dioscorea, the trees producing fruits or nuts like Anonidium mannii or Panda oleosa, could be very patchy. There are in contrast, some examples of resources that can be cropped in places where they are highly concentrated: some mushrooms like 
Termitomyces, growing in large amount on the termite hills, or the Dioscorea minutiflora, the only yam covering large areas in the undergrowth because of its stolons. Caterpillars may also be considered as a concentrated resource considering the large amount of larvae falling from the tree at the period of nymphosis. Similarly the fruits falling from large trees (such as Irvingia gabonensis or Baillonella toxisperma in Cameroon) producing very large amounts can be also considered as 'concentrated' food resources, although the trees bearing such fruits are widely scattered.

We find striking differences, comparing rain forest to the subdesertic environment of the Kalahari Bushmen (Yellen and Lee 1976), a specialised ecosystem with few species, highly localised in space, and extremely variable from one year to another, due to the arid climate. The water supply is the major concern of people, determining the characteristics of home ranges as well as seasonal migrations (cf. Barnard, this volume).

\section{The Pygmies of the Ituri Forest, Eastern Zaïre}

The discussion about territoriality among African Pygmies began with the data published by Turnbull about the famous Mbuti Pygmies, well known since the historical works of Schebesta (1952). Turnbull (1965) opposed the non-lineal band of the Mbuti to the patrilineal model generally proposed for hunter-gatherers; he later examined their flexibility and defined the notion of flux (1968). More recently the residential groups of the Mbuti were re-examined and the conclusions of Turnbull somewhat questioned (Tanno 1976, Ichikawa 1978). However these studies are more complementary than contradictory, as pointed out by Terashima (1985).

The term 'Mbuti Pygmies' covers actually several groups, differing in language, technique and region. Not all of them are known to the same extent. Differences between 'archers' and 'net hunters' offered opportunity for endless discussions about the influence of the natural environment on these hunting techniques (Abruzzi 1979, Harako 1981, Milton 1985). However the data are very weak about the precise linguistic situation of these different populations, as well as the real similarities they all have. Neither cultural nor lexical comparisons are available, and hence I will use the name Mbuti for the Bantu-speaking Pygmies, and Efe for the Sudanic language speaking Pygmies, the so-called 'archers'.
Social Groups

The Band The residential groups of Mbuti and Efe Pygmies are al called band in the literature. These groups are fairly large among the Mbuti, counting about thirty adults, that is to say twelve to fifteen households or nuclear families. The Efe groups are smaller, with an average of eight households, and less than twenty adults (Turnbull 1965, Ichikawa 1978, Terashima 1983, 1985).

Every individual in the band is related to every other, through clear consanguineal or affinal bonds (Turnbull 1965: 274). A majority of the men live in the group of their father or father's relatives; however widows or divorced women usually return to their natal bands with their children, who are then raised in this maternal band (Tanno 1976: 129, Ichikawa 1978: 181). Marriages are generally virilocal, but uxorilocal marriages also exist, although less frequently. The newly wed couple are able to choose their place of residence, according to emotional as well as economic considerations (relative size and composition of the two bands, Turnbull 1965: 275). A table published by Terashima (1985:111) shows that about three-quarters of the male members of a band live in their paternal kin group, but one fifth live in their maternal kin group and one-fifth in the family of their wife.

Lineages Both Mbuti and Efe societies are divided into several patrilineal descent groups (Mbuti: banama, Efe: acu); each patrilineage has its own animal which none of the members is allowed to eat (nginiso is the Mbuti name for this 'totem'). Because of the important proportion of patrilocal members in a community, obviously these members belong to the same patrilineage; as stated by Ichikawa (1978: 181), the core of the band is patrilineal. However, the proportion of people related by women in the band is quite significant, as seen above, in such a way that several patrilineages are represented in the same band, allowing Turnbull (1965) to consider the band as non-lineal. Actually, he counted an average of six different lineages in the Mbuti camps, and four in the Efe camps (1965: 99) (see Table 6.2).

Ichikawa reported the case of bands composed by two cores of different lineages, which he names dyadic bands (1978: 151). This composition seems to be due to sister-exchange marriage, because men having exchanged sisters often live together (Terashima 1985: 114). People cannot marry persons belonging to the same patrilineage 
Table 6.2 Lineal composition of Mbuti and Efe bands

\begin{tabular}{|l|c|c|c|c|c|}
\hline & N. camps & N. huts & Total lineages & Male members & Female members \\
\hline Mbuti & 6 & 94 & 35 & 26 & 29 \\
Mean & & 16 & 6 & 4 & 5 \\
\hline Efe & 7 & 76 & 30 & 20 & 22 \\
Mean & & 11 & 4 & 3 & 3 \\
\hline
\end{tabular}

Source: data in Turnbull 1965: 99

banama, which is exogamous (Turnbull 1965: 97, Ichikawa 1978: 145). Matrilateral relatives are named noko by the Mbuti and adi by the Efe, and neither Mbuti nor Efe can marry people from among their maternal relatives (Terashima 1985: 114).

\section{Spatial Mobility and Dynamics}

Mobility and Task Groups Camps move five to seven times a year, the period of stay in one camp varying from fifteen to seventy-five days. The distance separating one campsite from the following is 5 to $8 \mathrm{~km}$, that is to say one or two hours' walk.

Evidence of the existence of several levels of social organisation was established by Helm (1968), who distinguished task groups, local bands and regional bands among the Dene of Canada. In the same way, among Mbuti Pygmies authors distinguish between band, sub-band and hunting group as different levels: bands may split up in sub-bands, or aggregate in hunting groups (Ichikawa 1978: 182).

Task-groups do not always result from a spatial split of the band; they vary in size according to the different activities. Several hunting techniques involve different types of teamwork (cf. Turnbull 1965, Harako 1976, Tanno 1976, Terashima 1983). Both Mbuti and Efe groups hunt arboreal monkeys with bows and poisoned arrows, and this is the only individual hunting method. Large mammals, like elephant, okapi or bush pig, are killed during spear hunting (Mbuti butuma), performed by a group of about five men, in both Pygmy societies. The major difference between Efe and Mbuti is the use of nets, by the Mbuti. Their collective net hunting (kuya) involves all the men and women of the band, to capture mainly the duikers. The mota (collective hunting) of the Efe involves only seven to ten men with some dogs, using bow and iron-tipped arrows to kill duikers, water chevrotain and porcupines. Another collective bow and arrows hunting, mosilo or begbe, is made by a large group, involving some thirty men and women, from several neighbouring bands. Gathering activities may also be collective, and nut-gathering teams are reported (Terashima 1985: 107), as well as honey collecting teams counting two or three men.

Both Mbuti and Efe are reported to practise a type of large-scale hunting, a very large net hunting for the Mbuti and the mosilo of the Efe, involving the cooperation of several bands. Harako (1976), Tanno (1976) and Ichikawa (1978) recorded that bands with different base camps sometimes gather to form a large hunting group.

Seasonality The Ituri forest has an equatorial climate, with a main rainy season (August to November), a main dry season (December to March), a minor rainy season (April to June) and a decreasing of rains, or minor dry season (July). The Mbuti annual cycle of activities may be summarised as follows: during the main dry season, net hunting is undertaken almost every day; the minor rainy season is the honey season (Ichikawa 1978: 133), as well as the nuts and wild yams season (Terashima 1985: 109); during the main rainy season, base camps are located close to the farmers' villages, and Pygmies are involved in agricultural work, doing only little hunting of few days duration in the forest (spear hunting, small net hunting, individual monkey hunting). Thus the annual moving cycle opposes a stay near the village at the border of their range during the major rainy season, and a move back towards the interior of the forest during the hunting season, when the dry season starts (cf. Turnbull 1965, Harako 1976).

The Efe annual cycle also opposes a hunting season in the forest at the end of the main dry season (February to April), and several periods of stay near the villages, from the end of the rainy season (September) to the mid-dry season (January), during which the Efe alternatively hunt and help the farmers working in the gardens. After the period of hunting, the groups again come close to the villages (April), going back into the forest for gathering of nuts and collecting honey, in the rainy season (Bailey and Peacock, 1988: 96).

Home Range Each band travels within a home range, which is called territory by all the authors. Each territory carries only one band. It extends in a long, narrow strip, from the base camp near the village to the interior of the forest (Turnbull 1965, Tanno 1976: 123, 
Map 6.2 Distribution of hunting paths and camps of Mbuti. Pygmies, Ituri forest

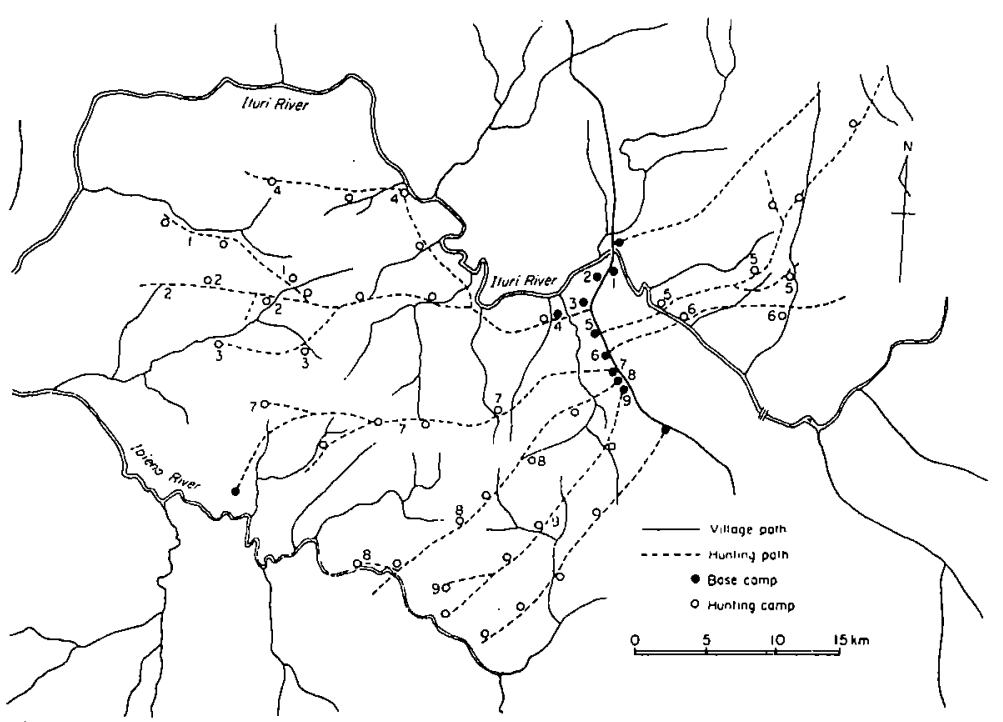

Source: Ichikawa 1978

Ichikawa 1978: 171). The boundaries generally extend one day's march in one direction, three days' march in the other (Turnbull 1965: 94). Tanno values at $30 \mathrm{~km}$ the length of a Mbuti territory, yielding $120-50 \mathrm{~km}^{2}$ (1976: 124); Ichikawa gives larger areas, also for Mbuti Pygmies, from 150 to $300 \mathrm{~km}^{2}$ (1978: 171). The territory is characterised by narrow paths, which connect several successive hunting camps (Tanno 1976, Ichikawa 1978) (see Map 6.2). Unfortunately, I was unable to find data about areas used by Efe Pygmies.

Turnbull, observing the importance of the fluctuation of membership of the band, argued that the notion of territory was 'the only concept through which the band can be defined' (1965: 93), and consequently 'the band can only be defined as the group of individuals living and hunting within recognised territorial boundaries at a given time' (1965: 137). This is emphasising the homology between a single band and its home range, justifying the term 'territory'. Lastly, the Mbuti name for territory is the same word as 'the forest' (ndura).
Flexibility After his work among the Mbuti Pygmies, Turnbull introduced the notion of 'flux', as 'the constant changeover of personal between local groups and the frequent shifts of campsites through the seasons' (1968: 132). All authors agree that the 'dynamic aspect is the essential characteristic of the band' (Ichikawa 1978: 181). The process of fission and fusion is quite simple: the band divides into small segments, within the band territory, each segment settling its own hunting camp; the sub-groups afterwards gather again in a single unit (Turnbull 1965: 100). As the camps move, the number of families and the composition of the band vary (Harako 1976: 91).

The Mbuti stay in a large-size band during the net-hunting season, in the forest (dry season: December to March). The second pole is the rainy season, during which the Mbuti settle close to the farmers' villages, forming small groups (Harako 1976: 91). Turnbull (1968: 135) reported also that the net-hunting season is the period when larger groups are formed, but that the focal point of the process was the honey season (minor rainy season: April to July), during which the net-hunters spread out into fragmented sub-bands (see Figure 6.1). Harako gave an example of flexibility among one band of Mbuti, near Lolwa (east of Epulu), in the years 1972-3: near the village, they were five families from August to November; they moved and became six families in the forest from December, and eight from January to February; yet ten families gathered for the hunt during the dry season, until June (1976: 91). In this case we can see that the Mbuti band remained in its large-size shape during only five months, being divided into smaller units during most of the year.

The Efe Pygmies also present a similar flexibility, but in a reverse process: the band is gathered in large-size while settled near the villages and is fragmented during the forest trips. Harako (1976: 47-8) detailed the calendar of an Efe band near Lolwa, in 1972-3, where the base camp near Lolwa counted twenty-five families (end of rainy season: September-October), who dispersed in various sub-groups from about eight or ten families settled farther into the forest for the rest of the year. This means that this Efe band was in its largest stage for only two months, and was dispersed during the ten remaining months. The Efe band is gathered during the rainy season, near the village, and is divided most of the year, into three or four small sub-bands; the Mbuti band is on the contrary separated near the village, also in the rainy season, and gathered in the forest 
Figure 6.1 Seasonal changes in the composition of a Mbuti camp

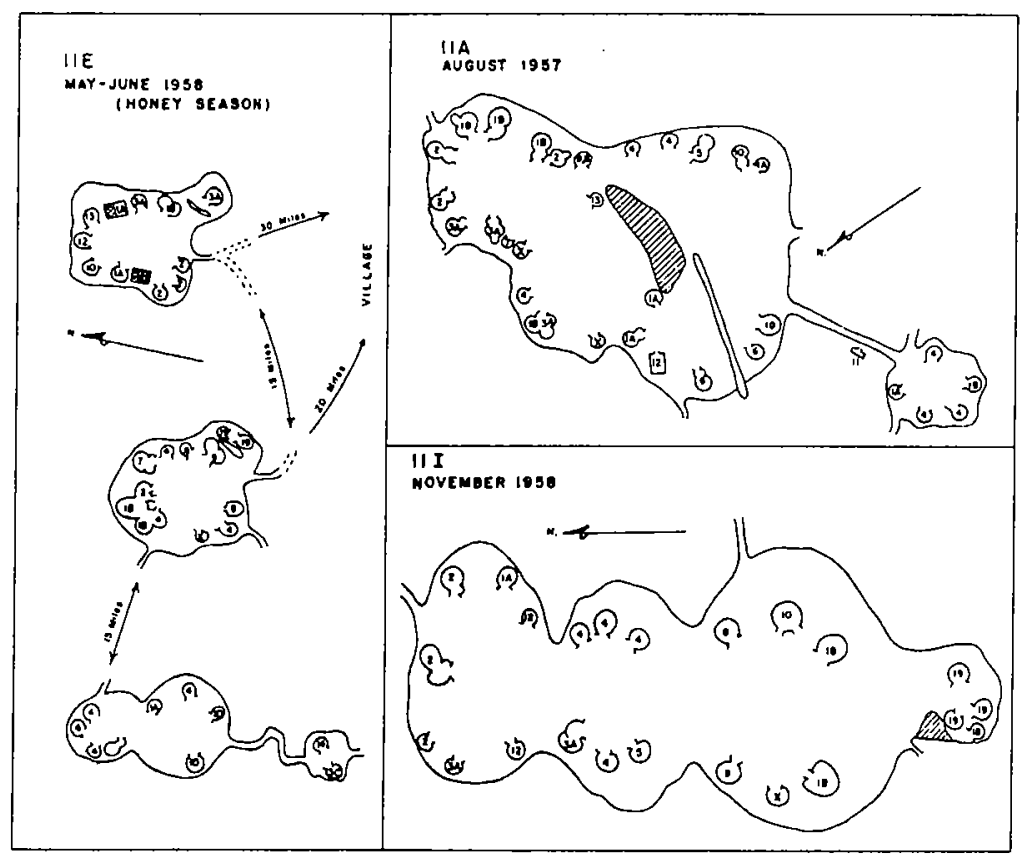

Source: Turnbull 1965

for almost half of the year, but mainly around the dry season.

Turnbull (1965: 107) already emphasised this opposition between net-hunters and archers, the pivot of which seems to be the honeyseason (minor rainy season): during this season, the archers' band aggregates, while net-hunters spread out into fragmented sub-bands (1968: 135). Turnbull relies on these characteristics to conclude that the major function of the process of flux is 'conflict resolution', that is to say a political more than an ecological adaptation (1968: 137), even if the basic size of the band may be explained by the major hunting techniques practiced by the net-hunters or by the archers.

Social Access to Resources Every member of a band is allowed, with his nuclear family, to live, hunt and gather everywhere within the band territory. Birth is the very first basis of integration into a band, conveying the right to hunt with that band throughout life (Turnbull 1965:276), the second being marriage. However, in addition to the periodical fragmentation of the band, changes in its composition are also due to the presence of outsiders. This signifies that other people are allowed to come and use a territory.

The habitual exchange of visits is, in fact, the major social communication that exists between one band and another (Turnbull 1965: 96), and every author mentions the presence in the communities, of families coming from other bands. For instance, Tanno (1976: 108), shows that the families joining the band come from neighbouring groups, with which sister exchanges took place in the previous generation. Turnbull established very clearly that 'the importance [of marriage] lies not in the initial or future residence of the married couple, but in the exchange relationship established by their marriage, enabling individuals or families of each band to exchange visits with members of the other' (1965: 286). Thus cognatic and affinal relationship are utilised to acquire access to the resources of other territories. The Mbuti themselves express the lack of relatives in other bands, by the expression 'to walk emptily' (1965: 286), thus emphasising the necessity to have friends elsewhere for travelling to. During the visit, the travelling family becomes a full member of the band, acquiring the same rights as the others to work and hunt here.

\section{Relationship with Villagers}

There are numerous ethnic groups living in the Ituri region, who entertain relations with the Pygmies; the Bira (Bantu-speaking people) and the Lese (a Sudanic-speaking population) are most commonly cited but they are not alone. Obviously the type of relationship with the Pygmies, as well as the way of life within the forest, differ greatly from one group to another. For instance, the Bira do not seem to be at ease in the forest, and they seldom or never hunt with the Mbuti; the Lese, however, are well adapted to the forest, and sometimes they have joint hunting parties with the Efe.

Every Pygmy, Efe as well as Mbuti, entertains regular relations with a specific villager. These relations are based upon economic exchanges: the Pygmy supplies 'his' villager with game meat and honey, receiving in exchange iron tools and starchy food from the gardens. Nowadays, all the Pygmies also help the farmers for some 
seasonal agricultural task, like the slashing of new plots, or the harvesting of rice (cf. Turnbull 1965). The participation of all the Pygmies in the agricultural work of the villagers has an important spatial consequence: a majority of the groups come close to the villages at the key seasons. Cultivators of plantains and cassava, the villagers slash and burn the new fields every year in the dry season, and they need the help of the Mbuti and Efe men for felling the trees. When they cultivate peanuts and rice, the village women use to ask the help of Pygmy females for harvesting and carrying the crop to the store, near the end of the rainy season (cf. Harako 1976, Ichikawa 1978, Bailey and Peacock 1988).

Outside these particular seasons, it is reported that the Pygmies come closer to the villages during the heaviest rains, when they feel there is more food supply in the gardens than in the forest (Harako 1976: 45, Bailey and Peacock 1988: 96). At this time, the men go hunting from their village camp, while the women help the female villagers in the gardens. During the minor rainy season, some groups also feel uncomfortable in the forest and settle again near the villages. This corresponds for the villagers to the time of some shortage in food supply, in such a way that conflicts between villagers and Pygmies become frequent, provoking a possible change of affiliation with a particular village (Bailey and Peacock 1988: 97; cf. also Ichikawa 1978) and migration towards another place.

The evident differences between the data and the interpretation of Turnbull on the one hand and his Japanese and American successors on the other, could be interpreted more in terms of change than, as they too quickly do, in terms of question and dispute. It is also in this way that Turnbull (1983) tried to interpret the differences. It is necessary to remember the length of time that separated the various field studies, and what drastic political changes occurred in Equatorial Africa: Turnbull worked in Ituri between 1951 and 1959; Independence came in 1960 in the midst of hard times; other very serious troubles, including a civil war known as 'Révolte des Simba', began in 1964. It was several years later that the Japanese team began its research in late 1972, the American scholars arriving in 1973 (Hart) and later on in 1980 (Bailey). Between the 1950s and 1980 s, the tendency for the Pygmies has been to stay longer close to the villages; they have also increased their hunting efforts, because of the importance of the meat trade (cf. Hart 1978). The direct consequence is that they never stop hunting: even during the honey season, which was previously the main fragmentation period (Turnbull 1965: 106), the bands no longer divide into smaller units and net hunting continues (Ichikawa 1978: 169).

\section{Aka Pygmies of the Central African Republic}

\section{Social Groups}

The Camp The basic socio-economic unit is the camp, which is a local group, counting less than twenty adults; in a typical camp, there are six or eight different huts, or nuclear families. For the majority, the inhabitants of the same camp are members of an 'extended family': men and women are related not through the father, but the grandparents and the uncle, who are designated by the same name $k 5 k j$ (see Figure 6.2). The breadth of meaning of this term has an important function in the cohesion of the local community.

We can summarise the types of links existing between the inhabitants of the same camp. Firstly, birth: someone lives in the community of his parents. Secondly, marriage: the presence of a married daughter in the camp of her father and mother is usually temporary, lasting the first years of her marriage, due to the system of bride service (bò ${ }^{\prime} p \grave{\varepsilon}$ ). After the birth of the first child, the young couple goes back to the camp of the husband's parents. However there are many cases in which the son-in-law stays in his wife's camp. If the husband's community is large and the wife's smaller, or if the young man feels comfortable with his parents-in-law, he will stay there; if the camp of the parents-in-laws is really a very small group, they may join the native group of their son-in-law.

Birth, marriage, but also emotional links combined with economic advantages: even after marriage, sisters and brothers may still live together, or a young couple may follow the mother of one of them when she marries again. Widows, or divorced women, usually go back to their native community, the camp of their father or brothers. After the death of the father, a child may live with an uncle, either the father's or mother's brother. Therefore residence tends to be virilocal and patrilocal, but the bride-service is uxorilocal, and the personal choices mentioned actually make the residence bilocal (see Table 6.3). The census I made shows that, at the time, one third of the Aka lived in the community of their spouse (66 per cent of the families were virilocal and 34 per cent were uxorilocal). 


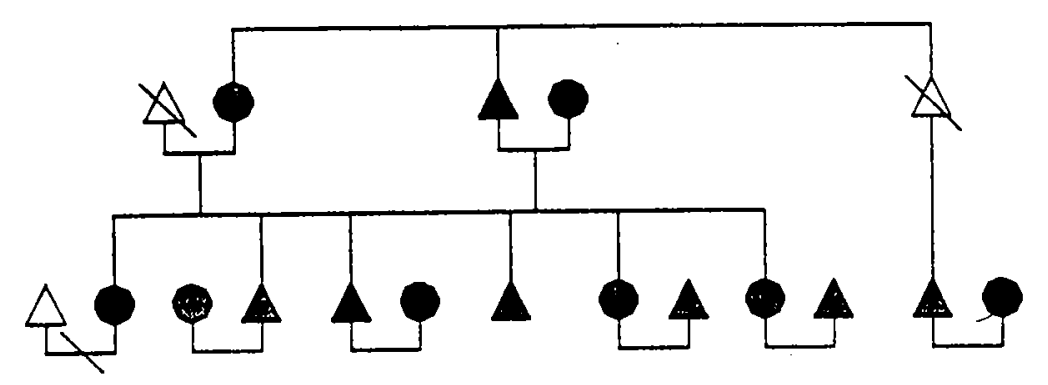

Table 6.3 Residence of adults in fifteen Aka camps

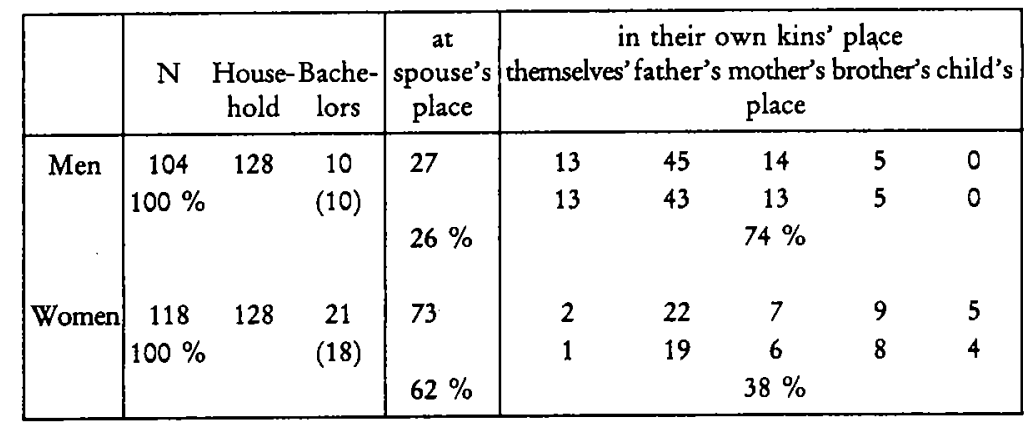

In Aka terminology there is no name for the nuclear family, nor for the extended family: people speak about 'my camp' (lángò wá $m u ̀)$, and 'people of my camp' (bàtò bá lángò).

Lineage and Kinship Another level of Aka social organisation is the patrilineage (dikàndá), in which every Pygmy is included by birth. But the composition of the local group is independent of the lineage, and in every camp we can find people belonging to different lineages. The mean is seven, among both men and women (Bahuchet 1985: 426).

Among the Aka the lineages of the women, those of the mother and all the grandmothers, are also important (see Figure 6.3). In addition to his own lineage, everybody knows the names of the lineages of his mother (i.e. the maternal grandfather), as well as his father's and mother's mothers. All of this kinship by women is called mòbilà.
Figure 6.3 Aka lineages and resources

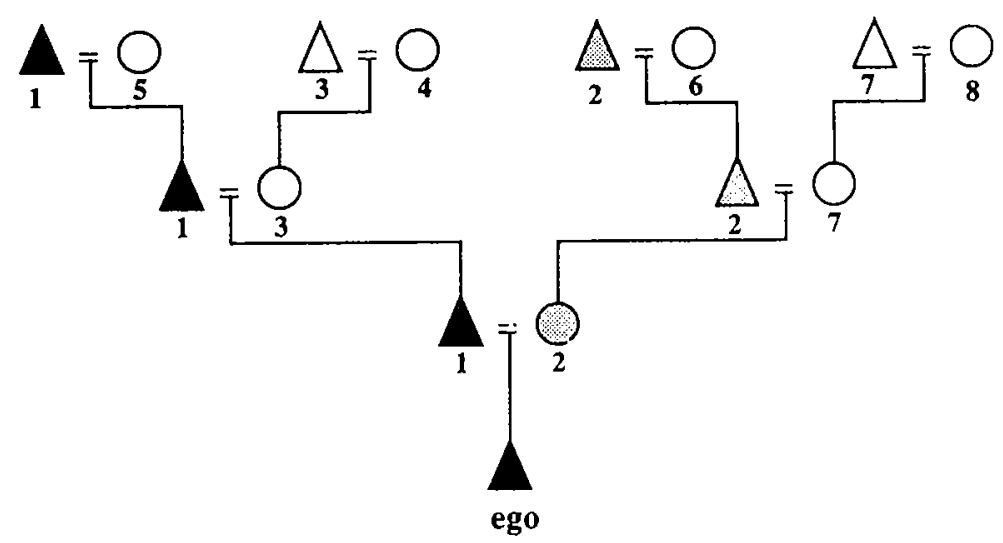

Figure 6.3a Access to resources through filiation

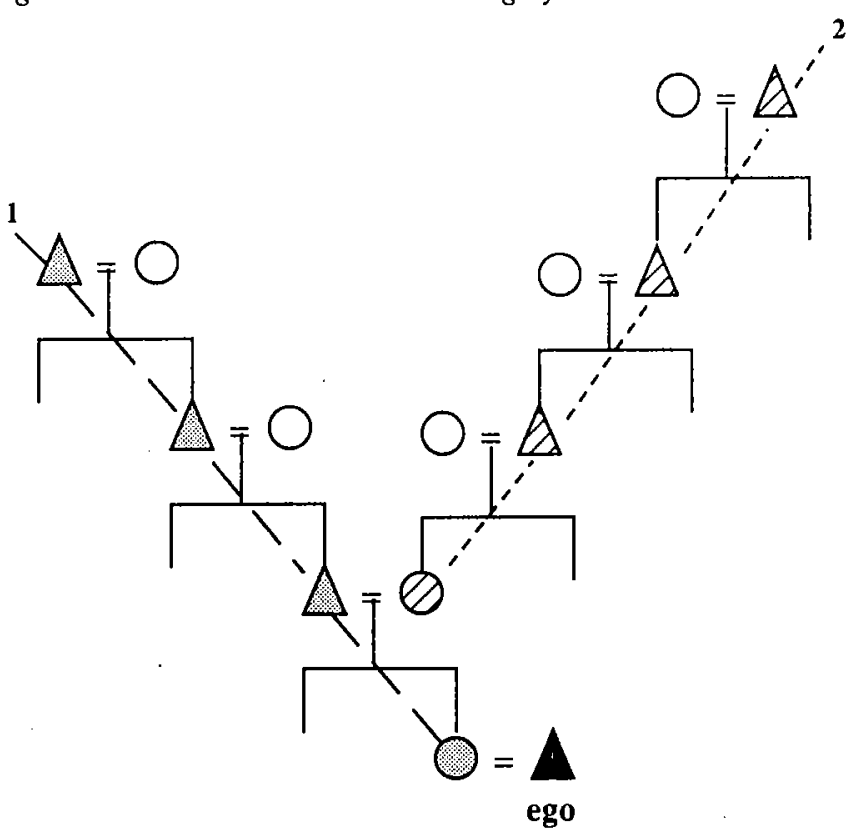

Figure 6.36 Access to resources through alliance 
Spatial Mobility

Camp Mobility Throughout the year, the local groups move on several times, six time on average. Two sites are usually separated by one hour's walk $(6 \mathrm{~km})$, and a community may cover some $50 \mathrm{~km}$ a year, from campsite to campsite. Around the campsite, the different subsistence activities lead the people closer or farther apart: the women gather everyday at less than 2 or $3 \mathrm{~km}$ from the camp, within a 12 to $15 \mathrm{~km}^{2}$ area; however specific gathering trips, such as mushroom gathering, can lead the nuclear families to several hours' walk $(5$ to $10 \mathrm{~km})$. Distances covered by men during hunting activities vary from 4 to $5 \mathrm{~km}$ for porcupine trapping, to $30 \mathrm{~km}$ for a day of net-hunting. In this case, the total area is about $80 \mathrm{~km}^{2}$, exploited over several weeks. The tracking of large mammals, mainly the elephant, can take the hunters to 60 to $100 \mathrm{~km}$, in a hunt lasting several days.

Task Groups and Seasonality From my own observations during fieldwork, and through oral information, I was able to compile a calendar of subsistence activities, both in the present and in the near past. $^{3}$ Climate is the major factor which opposes the two-month dry season (December-January) to the season of the heaviest rains (midAugust-October). There are only two seasonal resources: caterpillars (mid-August-mid-September) and honey (beginning of the wintering of the bees with the first heavy rains, June). There are three poles in the Aka year, that is to say from one rainy season to another ('year' and 'rainy season' are both known as dibuila): the gathering of the caterpillars and spear hunting by men, both during the rainy season, and the collective net hunting during the dry season. In between people practise activities like porcupine hunting, gathering of nuts and almonds (mainly Panda oleosa, Antrocaryon micraster, Irvingia gabonensis, I. robur, I. excelsa) or small-scale net or spear hunting, involving few hunters. The change in camp composition follows these three poles (see Figure 6.4). Net hunting necessitates the participation of many people, through the association of several camps. Spear hunting, however, is only performed by the adult males of the community, who track the large mammals for quite long distances, and for that they settle in special hunting camps by themselves, without the women, the elders and the children, who remain in the communal camp. This activity begins with the heavy rains, in July, because, they say, it is easier to 'read' and
Figure 6.4 Annual cycle of Aka groups around 1900

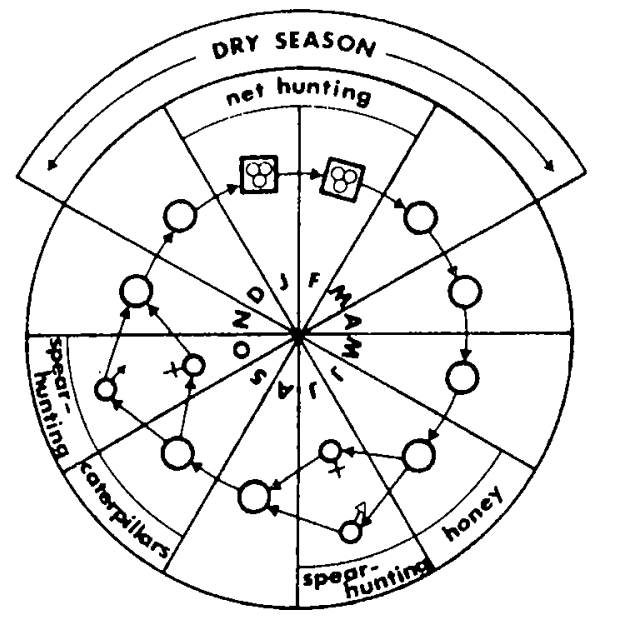

MIXED CAMP

$\sigma^{\prime}$ MEN'S CAMP

WOMEN Q CHILDREN'S CAMP

8. GATHERING OF SEVERAL CAMPS

follow the tracks, footprints and spoors of the game. When the mature caterpillars begin to fall, the men join the community, going back to their hunting activities a few weeks later, until the end of the rainy season.

Differences between the old days and the present are few. They concern mainly the participation of the Pygmies in the agriculture activities of the farmers. During the dry season, the villagers ask their Aka associates to help them for slashing and burning the new fields. Thus, many Aka communities tend to alternate one year of collective net-hunting in the forest, and one year near the village for agriculture (Bahuchet and Thomas 1985, Bahuchet 1988: 134). A second modification is the increasing use of snares and traps during the rainy season, instead of tracking large mammals. Thus the division into male and female camps during the rains becomes rarer.

Home Range All of these activities are carried out in a large area, used by a community year after year. The Aka use the word mòbànzé to designate this area, a word which also means 'side, region' (Bahuchet 1985: 405). This area corresponds quite well to the definition of the 'home range', this being according to Burt (1943 quoted by Jewell 1966: 103) 'the area over which an animal 
Map 6.3 Aka territories

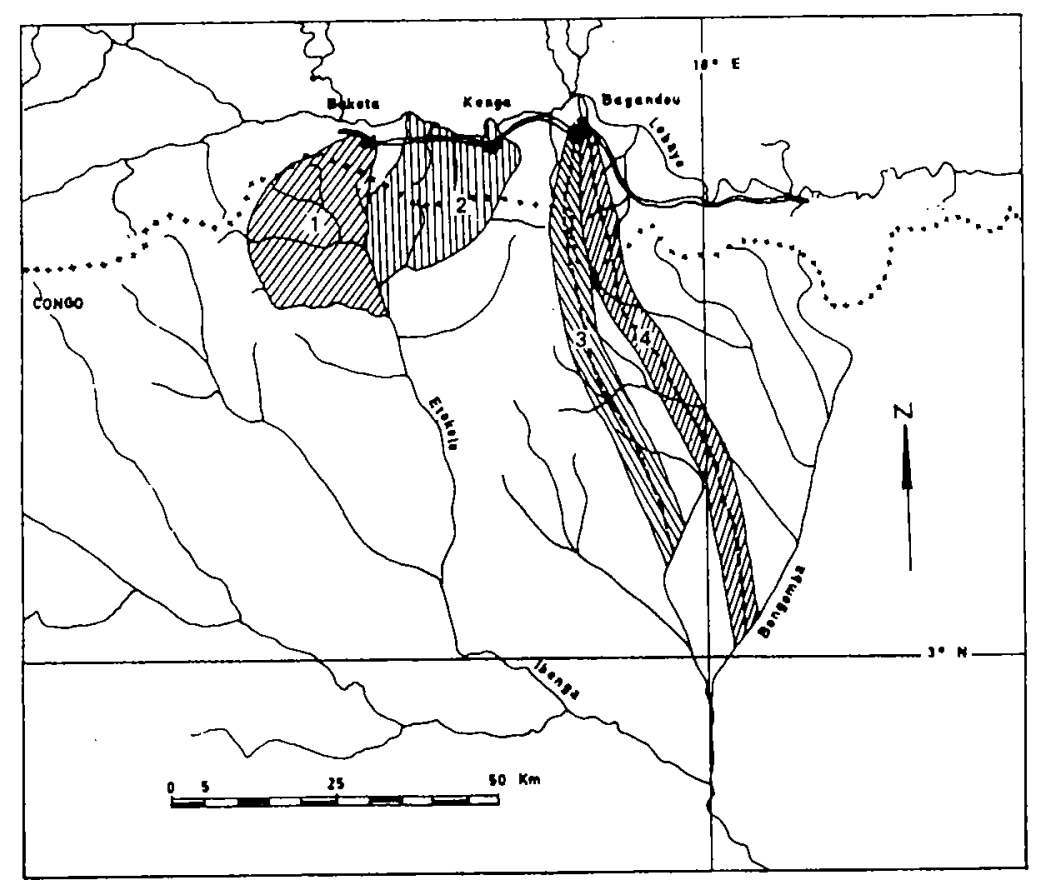

Rough location of the home ranges of four regional bands:

1 - the Bakota band

2 - the Kenga band

3 and $4-$ bands of the Bagandou region, centred around two

lineage tracks.

3 - Bokoka village (Bombolongo lineage)

4 - Lombo village (Bonzombi lineage).

The home ranges have an approximate area of $400 \mathrm{~km} 2$.

normally travels in pursuit of its routine activities'. Jewell also introduces other useful notions, like 'lifetime range', which means 'the total area with which an animal has become familiar, including seasonal home ranges, excursions for mating, and routes of movement'.

The shape of Aka home ranges, in different localities, shows some disparity. Some are trapezoids with $30 \mathrm{~km}$ in diagonal, others are
Map 6.4 Major trails used by the Aka Pygmies in the Lobaye region (C.A.R.)

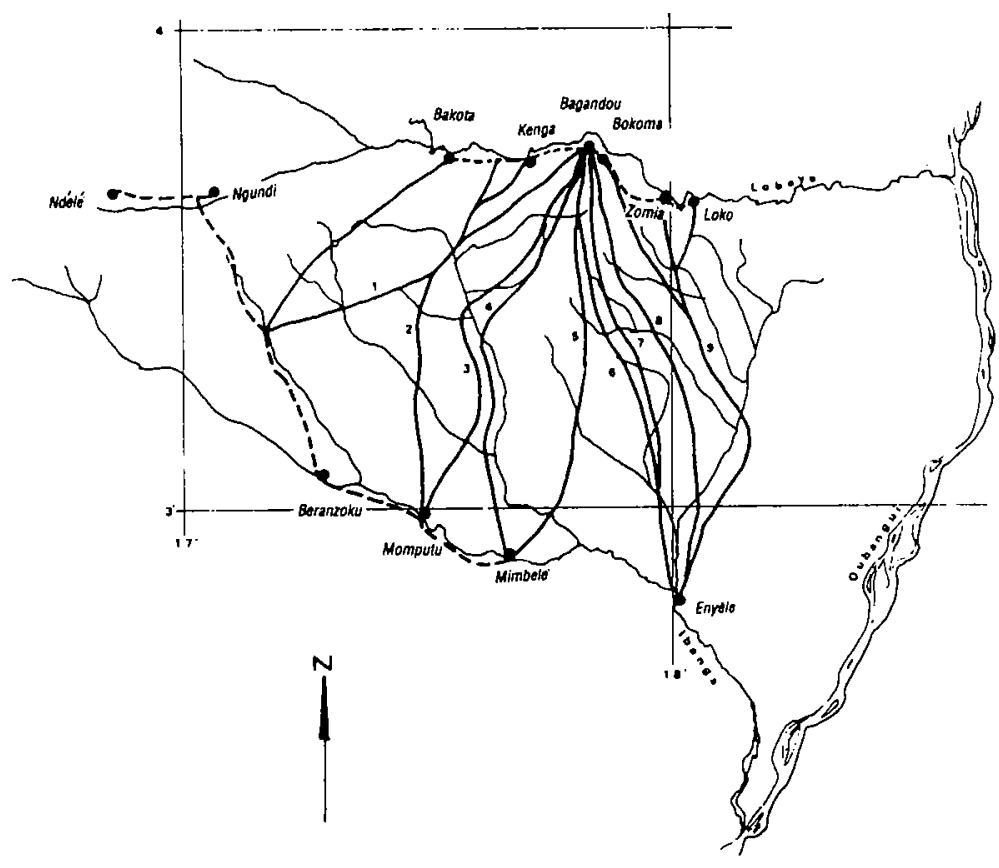

$0110 \quad 20 \quad 30 \quad 40 \quad 20 \mathrm{~km}$

bands $80 \mathrm{~km}$ long. However the areas are very similar, about 400 $\mathrm{km}^{2}$ (see Map 6.3). In some regions with high population density, like Bagandou in the Lobaye, the home ranges impinge on each other becoming literally filiform. This case reveals how this spatial system functions: when travelling, a person or a whole group uses a trail, $n z \hat{a}$. These trails are narrow but permanent, and go right through the home ranges. When moving camp, the Aka always use the path crossing their home range, and usually the campsite is settled only at a few metres. These paths are in limited number in a region, and it is possible to draw a map of them (see Map 6.4). 
Cooperation: the Gathering of Camps Living on every trail, there are several groups; these are always the same ones. Their numbers vary, according to the length of the paths, from three in Kenga to ten in the Bagandou region. This set of camps is called mòsàmbà and represents an important step in Aka society: these neighbouring local groups entertain special relations, more than with other groups living and travelling on different paths. Individuals and nuclear families often visit neighbours for joint activities, gathering or hunting. When all of these local groups join together, they settle a large camp, also called mòsàmbà. The function of this mòsàmbà meeting is the performance of the principal festival (mòkondî) during which the forest spirit èzÉngi appears under the shape of a raffia mask. This ceremony, lasting several days, is the major manifestation of the unity of the community (Bahuchet and Thomas 1985). This meeting of several camps allows a large number of persons to come together, thus enabling large net hunting in better conditions than a single group, which would be too small.

Nevertheless this mòsàmbà presents a less defined social structure than the camp or local group. We can call it a 'regional band' (Bahuchet 1979: 1003) but it is only a set of some groups living on the same trail with permanent contacts, without a describable structure. However, the Aka speak of 'set of camps' mòsàmbà, of 'neighbouring camp' dikángà, and of 'people of (my) trail' bàtò bánzâ. There are more marriages between neighbouring camps: in the regional 'band' around Kenga, with 3 camps and a total of 27 nuclear families, 13 nuclear families, in 3 generations, were constituted inside this band (see Figure 6.5). Finally, it is this band mòsàmbà which lives in and uses the home range mòbànzé.

A Kind of Territory? Territoriality in the animal world was described first for the birds; the concept of 'territory' was applied to 'any defended area' by Noble (1939) for birds and Burt (1943-9) for mammals; this definition was later made more precise by Pitelka (1959), (all quoted by Jewell 1966: 105): 'territory should be defined as an exclusive area, not merely a "defended" one'. This definition is also accepted by Eibl-Eibesfeld (1972: 323), when speaking of 'spatial intolerance'.

The Aka local group with its neighbours, the 'band', lives, hunts, gathers and moves in the same area. There is a definite number of camps which lives on the same path, and any newcomer has to present himself and to be identified. The spatial intolerance is
Figure 6.5 The Aka band around Kenga (Lobaye)

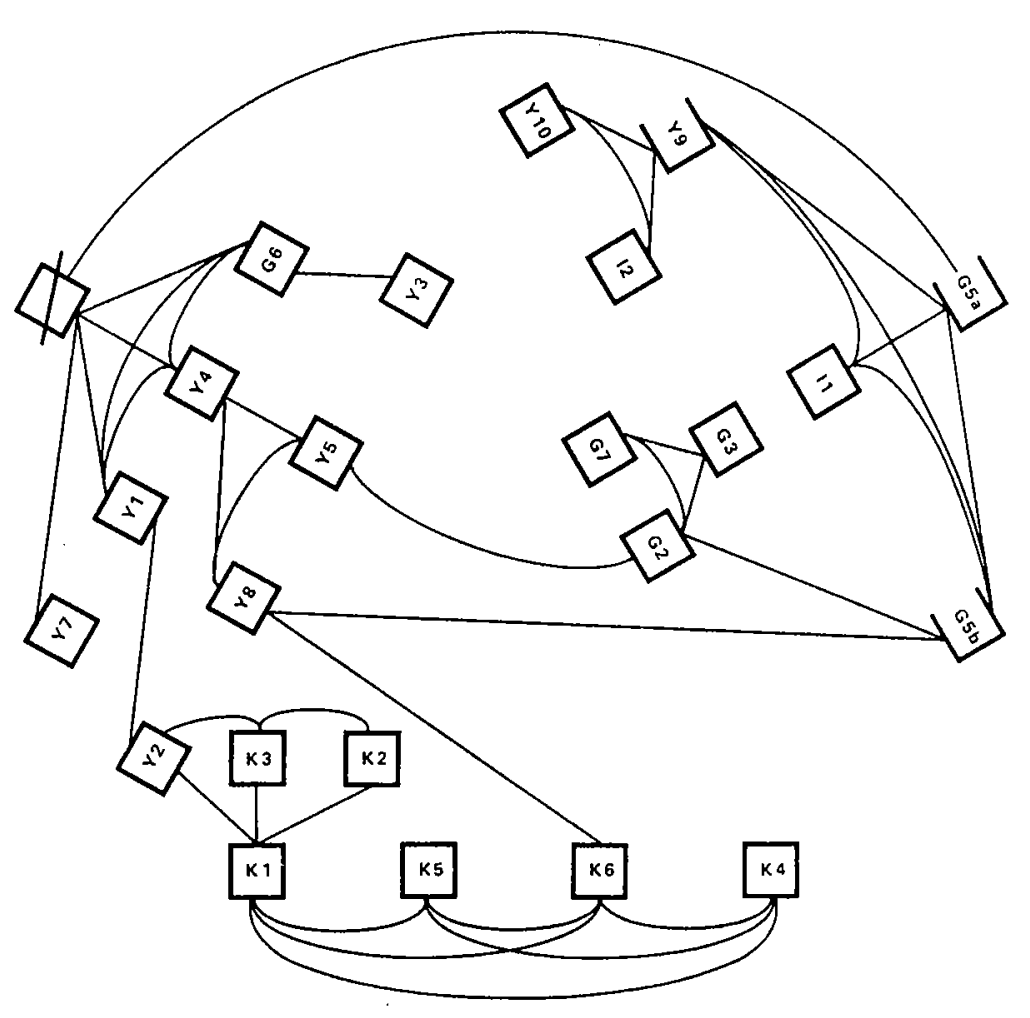

Key

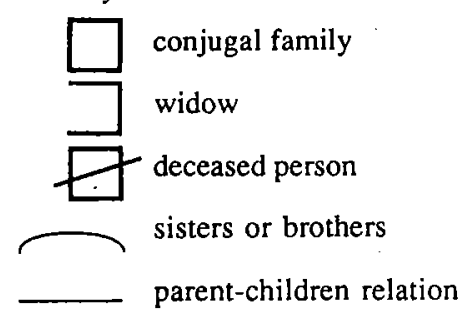

Note: This band is composed of three local groups. This figure summarises the relations between all the nuclear families of the band. $Y$, $\mathrm{K}$ and $\mathrm{G}$ mark the name of the group (Yenbu, Kolaki and Goti) and the number identifies the family. Thus no family appears isolated. 
obvious: a group never tries to settle on the trail of another group, without preliminary agreement. Thus it is possible to call the trail a 'territory', in the strict ethnological sense. The economic life of the Pygmies is carried out on the same territory. Their spatial mobility is effective within the territory (thus the Aka Pygmies are mobile only in a limited area). A quarrel will always occur in case of transgression of these customs, and may be assimilated to a ritualised fight. As a matter of fact there is almost never active fighting. The specificity of these territories resides in the fact that all the trails start from non-Pygmy villages of the agriculturists with whom Aka have exchange relations. We will examine later in what way the relationship between Pygmies and farmers affects the use of space.

We can now summarise the characteristics of Aka mobility: a whole community, constituting a camp, always moves along a trail which is the axis of its home-range; one extremity of this axis is the village of the 'Tall Black' farmers. Camps move several times a year along this path, without any clear correlation between the rhythm of movement and the seasonality, except when participating in the work in the fields of the villagers. Travels outside the path may occur, but only as migrations in the case of dramatic conflicts.

Access to Resources

Resources Appropriation Food procuring activities of the Aka Pygmies are very diverse, and very few foodstuffs follow specific rules of ownership. Among fixed resources, several trees may be marked when found, like fruit trees (Pancovia, Synsepalum) or nut trees (Irvingia, Panda or Antrocaryon), also trees bearing nests of hornbills or parrots; but these are only marks of location for finding this tree again at the right gathering time. Only trees with honey nests (bee hives) are marked with marks of true ownership. If someone gathers the honey already discovered by somebody else, he will, if found out, be in trouble and have to fight or pay for it with iron blades. There is no limitation in the gathering of yams or mushrooms, two highly prized resources.

As far as the acquisition of game (mobile resources) is concerned, the only restricted appropriation is trapping: nobody can take an animal caught in a snare laid by somebody else. It seems also that it is difficult to set traps close to others'.

Ownership is hence not assigned directly to wild resources, but to such resources once they are appropriated by someone. The nuts or the caterpillars belong to the person who put them in her basket; the game belongs to the hunter who killed it (or more exactly to the owner of the weapon with which it was killed, Bahuchet 1985: 361)

Due to the territorial aspect of the path, there is a restriction to access at the place where all the resources are. But once a family or a group is allowed to settle, and therefore work and live in the territory of another group, their is no more restriction on their access to resources. However, what is exclusive is the path, not the forest area around it: a group cannot settle on the path of some other group without previous agreement, but during hunting or long tracking, the hunters may cross a trail other than their own.

The Notion of Ownership At this point it is necessary to examine the Aka concept of ownership. In Aka vocabulary, the noun konza can be translated by 'owner', but its broad use necessitates analysis: it is used for the 'owner' of a tool, but also for the villager with whom an Aka has a regular economic relationship, the 'patron'. It also designates the 'leader of a song' (kònzà wá lémbò) and the 'leader of a camp' (kònzà wá lángò). Much more, the same term characterises the relationship between the Spirits and the Forest: they are the konzà of the Forest. What these meanings all have in common is more the concept of being 'responsible for' rather than 'owning', whereby the Aka notion of ownership is based upon the responsibility of everybody for ensuring the prosperity of everybody, i.e. the community.

Social Access to Resources The ownership of food resources is offset by the rules of sharing that I described elsewhere (Bahuchet 1990). The game 'owned' by its killer is shared between the hunters who participated in the hunt. The pattern of butchering and the distribution of the shares differ for the spear hunting, for the net hunting and for the trapping. Each share is redistributed by every hunter in his family (elder relatives, grandparents and parents' brothers). Every wife then prepares the meal, and after cooking, distributes platefuls to every hut in the camp in such a way that, of the meals each household consumes every day, some are prepared by the wife and others come from neighbours. The distribution of the gathered products (leaves, tubers, caterpillars, nuts or mushrooms) follows this pattern. There is no obligation to share what is collected; everybody may give freely to whom he wants (parents, 
elders) if there is enough. The only true sharing in this case remains the distribution of cooked food.

A very important rule to be mentioned is that the owner of game, the hunter who killed the animal, is forbidden to eat its meat (Bahuchet 1985: 375). This rule is applied to game killed with a spear or an arrow, or in a trap, but not to an animal killed directly by hand or in the net (usually by stunning).

Both rules and practices allow every household of the camp to obtain a portion of the resources collected by some member of this community, and the only way for someone to have access to food resources is to be a member of such a community. In addition to the group to which one belongs by birth, as already stated, every Aka is linked with other groups. More precisely, every Aka is considered a member of any group in which people of the same patrilineal descent group as himself, and also of the lineages of his mother and the whole mòbilà kinship as described before (i.e. seven lineages), as well as the lineages of his father's and mother's spouse live. Thus every $A k a$ bas free access to the territories used by members of ten different lineages, without any trouble (see Figure 6.3).

What Kind of Resources? What goods and materials do the Aka consider indispensable to normal life? The most evident circulation is that of food, with different levels of sharing, in the productive group and in the consumer group. Nevertheless in Aka society, portions of food are not distributed outside the camp. Meat is by far the most valued food, with honey being of highly symbolic importance. The primacy is underlined by the fact that only hunting and honey collecting are preceded by special rituals; on the contrary, gathering is never an occasion for ritual ceremonies (Bahuchet and Thomas 1987)

The circulation of objects seems to be more important, since this goes beyond the limits of the residential group. Thus, when elders visit a camp, their younger kin give them objects made by village craftsmen (weapons like spears, tools like knives or axes, cooking pots). Also for the bride-price, the young man and his family have to bring the in-laws a net, an axe and several spear blades, besides regularly supplying meat to the future father-in-law during the courtship (or 'marriage service'). For the Aka, the acquisition of iron is a problem at least as serious as the food supply, because iron is a material which is the basis for their whole food production process, and one which they do not know how to forge. For them, a
Figure 6.6 Aka socio-economic system

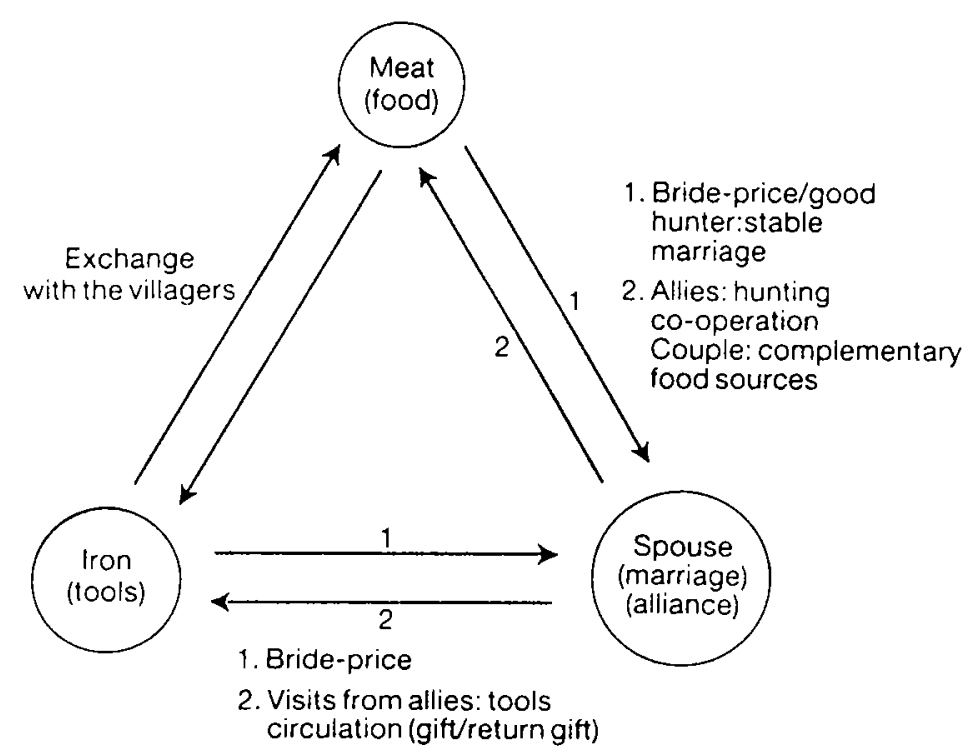

Source: Bahuchet 1988

lack of iron leads to technical impossibilities and therefore to food shortage.

I showed elsewhere (Bahuchet 1988) that the three elements essential for life for the Aka are meat, iron and a spouse (see Figure 6.6). All the Aka's efforts, all their social mechanisms are concentrated on guaranteeing each individual access to these primary necessities. In this way, to get food an individual must join a group, and the supply of meat requires a mutual aid network; but acquiring tools necessitates a circulation network, because it does not depend on Aka technical skill. This circulation network, partially based upon birth and sibling relations, is mainly formed by marriage. This alliance of families gives rise to temporary associations for hunting activities, and visits between in-laws are important opportunities for access to other resources. This network may be analysed as a process of 'risk pooling', as demonstrated by Wiessner (1977) for the San hunter-gatherers.

The social practice of the Aka focuses more on the access to and the distribution of tools than those of food. For the Aka, uncertainty 
is located primarily at this level and therefore it is not essentially concerned with food.

The Lineage Network The access rights which every individual Aka has to territories of members of ten different lineages has important spatial consequences. We have to remember that in a camp there are representatives of several lineages (the mean is seven), and that the members of the lineages are very dispersed. Thus every Pygmy is part of a lineage network, covering the whole Aka country.

This patrilineage system seems mainly to be a way of creating kin-like relationships with individuals too remote to belong to someone's classificatory kin group. It is the best way to incorporate into the family everybody unknown before. The lineage network plays the role of a real mutual aid network, allowing families to use resources on the home ranges of others. On some very rare occasions a family can migrate from its territory to the territory of other relatives, and thus the lineage network is also an organisation for potential assistance.

\section{Spatial Dynamics}

Flexibility When some fraction of the community moves without the other members, we can speak of flexibility. Usually the conjugal family as a whole travels together. Within the territory, the conjugal family seldom splits for economic purposes during more than a few hours: the kind of activities which involve only the conjugal family (mòl ĺngànò, 'walk'; includes at the same time hunting porcupines and gathering nuts and mushrooms), do not necessitate the settlement of special camps. However the nuclear family may travel to reach the village of their patrons, or to visit their relatives in other communities, in or outside the territory. Nevertheless these conjugal families consider themselves as part of their original community to which they return, whatever the period of their absence may be.

Individuals who leave their camps are mainly the young bachelors. A study of 109 Aka Pygmies by Hewlett et al. (1982) was aimed at their individual mobility, and the exploration of the area in which they live over their lifetime. To obtain a good estimate of the probability of a person ever having visited a given place, they measured the 'exploration range' by defining the 'half range' as the median of the distances from places of residence to places visited at least once (1982: 422). In Ndele (western part of the Aka region), the mean half-range was found to be $34.9 \mathrm{~km}$, with noticeable difference between the sexes: $58 \mathrm{~km}$ for the men and only $32 \mathrm{~km}$ for the women. This survey showed also that exploratory activity is mainly developed by boys between ten and twenty-five years old. Young men are much more mobile than girls, and in this way, they are able to choose their spouses from a larger sample. After marriage, the husband moves mainly with his conjugal family.

The Visits The visit is the major factor of social mobility. Aka vocabulary distinguishes between two types of visit: the visit in the vicinity (or neighbourhood), mòsèsélánù, and the long-term visit, bobuttù. The first is very short, lasting just a few hours, between people living in camps which are close together, sometimes just for chatting, for a joint gathering party, or often for dancing at night. During mòsèsélánù, people never sleep in the visited camp. Thus it is not a factor of mobility. During a long-term visit, the nuclear family travels far from its native community, and resides for several weeks, or months, in another camp. There, the visiting family is as active as the others in the camp, hunting and gathering together. In the visited communities married children, brothers, sisters, parentsin-law or uncles live.

During the year, in every local group, one of the nuclear families is living somewhere else for some months, while two or three other families will pay a visit to some relatives living in this camp (see Figure 6.7). In this manner, a Pygmy local group is always changing in composition, but always with a well-recognised nucleus.

Hewlett et al. (1982) showed that there is a correlation between frequency and distance (see Table 6.4): in half of the visits observed the destination was less than $50 \mathrm{~km}$ from the camp (see Figure 6.8). However these authors do not distinguish visits on or outside the path, but only outside the camp. Of 1,383 visits described, twothirds were repeated in the same place, for only 510 cases 37 per cent) was the locality visited only once. The principal reason given for these journeys was to visit the family ( 45 per cent of the cases), far more than work for villagers (23 per cent), hunting (20 per cent) and dancing (12 per cent). This last point is very important, because these dances are actually collective ceremonies and large religious festivals involving the participation of numerous people. Moreover dancing meetings are said by the youth to be the best opportunities to find a spouse. However these trips usually involved people living 
Figure 6.7 Number of visits among Aka Pygmies

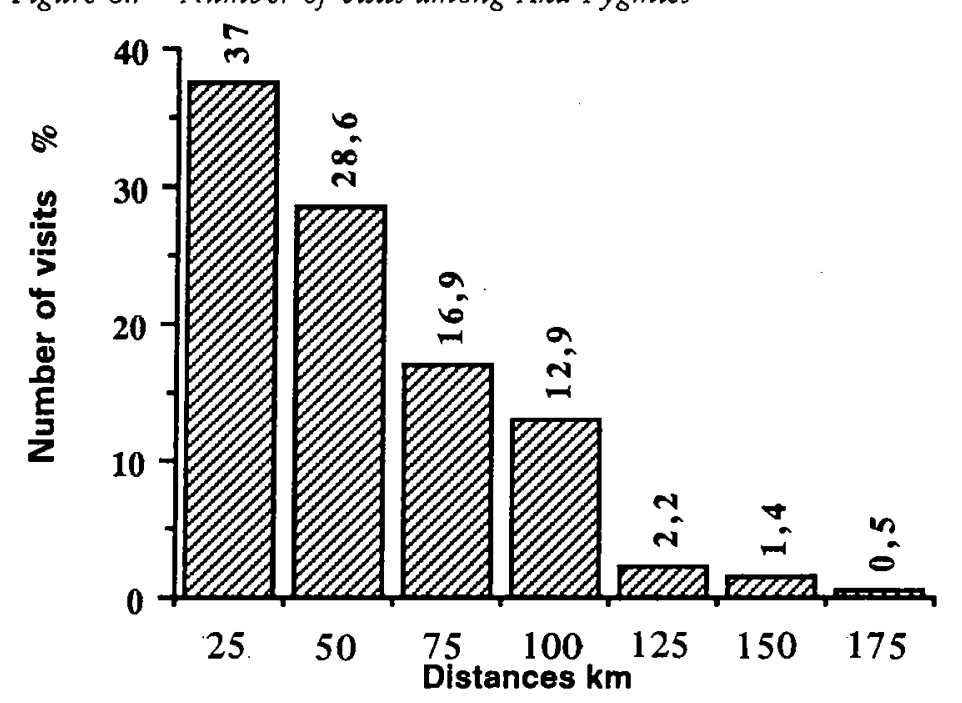

Source: Hewlett et al. 1982

Figure 6.8 Frequency of visits among Aka Pygmies

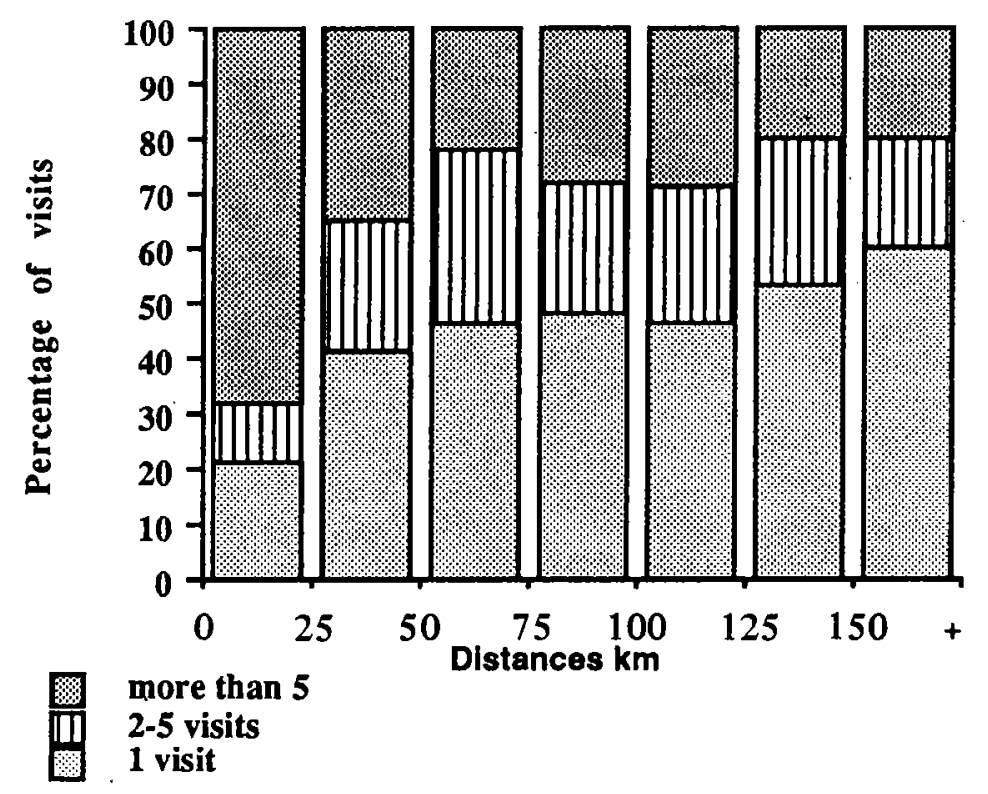

Source: Hewlett et al. 1982
Table 6.4 Causes and frequency of visits

\begin{tabular}{|c|c|c|c|c|c|c|c|c|}
\hline $\begin{array}{l}\text { NUMBER } \\
\text { OF VISITS }\end{array}$ & \multicolumn{2}{|c|}{ Family } & \multicolumn{2}{|c|}{ Hunting } & \multicolumn{2}{|c|}{ Dancing } & \multicolumn{2}{|c|}{$\begin{array}{l}\text { Work for } \\
\text { villagers }\end{array}$} \\
\hline 1 & \multicolumn{2}{|l|}{$38 \%$} & \multicolumn{2}{|l|}{$13 \%$} & \multicolumn{2}{|l|}{$27 \%$} & \multicolumn{2}{|c|}{$55 \%$} \\
\hline 2 & 9 & & 9 & & 5 & & 23 & \\
\hline 3 & 6 & & 2 & & 2 & & 6 & \\
\hline 4 & 2 & 62 & 1 & 87 & 1 & 73 & 2 & 45 \\
\hline 5 & 3 & & 2 & & 0 & & 1 & \\
\hline many & 42 & & 73 & & 65 & & 13 & \\
\hline $\begin{array}{r}\text { mean } \\
\text { distance }\end{array}$ & \multicolumn{2}{|c|}{$47.6 \mathrm{~km}$} & \multicolumn{2}{|c|}{$22.8 \mathrm{~km}$} & \multicolumn{2}{|c|}{$17.6 \mathrm{~km}$} & \multicolumn{2}{|c|}{$66.4 \mathrm{~km}$} \\
\hline
\end{tabular}

Source: Hewlett et al. 1982: 426-7

on very close paths. In the same way, the 'hunting' trips may only be cooperation between neighbouring camps, not necessarily living on different trails. On the contrary, the majority of the 'visits to family' are of course paid outside of the territory of the nuclear family. As stated by the authors, 'Aka would travel the greatest distances to visit relatives' (Hewlett et al. 1982: 427).

What we called the institution of the long-term visits is a way to permit access to the resources on a territory, to people who are not members of the local group. For the same reason, the lineage network plays the role of a real mutual aid network. In fact, what is forbidden, in terms of territoriality as spatial intolerance, is for a group of strangers to settle on somebody's path without asking and outside the lineage network. But as cooperation and mutual aid are a priority, the result of this Pygmy social mechanism is to reduce, to minimise territoriality. The second possibility given by this network is that of emigration. On some very rate occasions, when serious conflict occurs, mainly with villagers or with another family, a conjugal family or even a whole group may abandon its territory and migrate to reach the territory of remote relatives. This is a potential and rarely used insurance.

Social and Spatial Mobility of Individuals If we turn now to the mobility of individuals during their lifetime and through the generations, we observe that the first important occasion of social mobility is marriage: we have already noted that the husband lives in the local group of his wife till the birth of the first child. It is not 
Table 6.5 Distances between spouses in Bagandou region

\begin{tabular}{|l|cc|cc|}
\hline generation & \multicolumn{2}{|c|}{ identical } & \multicolumn{2}{c|}{ different } \\
\hline nowdays & 63 & $32 \%$ & 113 & $68 \%$ \\
parents & 81 & $40 \%$ & 123 & $60 \%$ \\
\hline Total & 134 & $36 \%$ & 236 & $64 \%$ \\
$\mathrm{n}=370$ & & & & \\
\hline
\end{tabular}

Table 6.6 Place of birth of Aka Pygmies

\begin{tabular}{|cc|ccc|c|}
\hline & Total & father's & $\begin{array}{c}\text { Identical with } \\
\text { mother's }\end{array}$ & both & Different \\
\hline $\mathrm{n}$ & 204 & 57 & 27 & 57 & 63 \\
$\%$ & & 28 & 13 & 28 & $31 \%$ \\
& & & $69 \%$ & & \\
\hline
\end{tabular}

unusual for this period to last many years, according to the choice of the couple. The fact that a youth leaves his parents camp when he marries means that his parents and brothers will visit him in his new in-laws' camp.

In order to evaluate both the mobility of people and the importance of travel, Hélène Pagezy and I made a survey in 1977 of 370 married adults in Lobaye, asking about their birthplace, and those of their spouse and parents. The results (Table 6.5) show that 36 per cent of the spouses were born on the same path, i.e. the same territory; that means two persons out of five chose their spouse from within the neighbouring camps. Cavalli-Sforza and Hewlett (1982: 266-8), putting slightly different questions at Ndele (western part of the Lobaye), also found that 34 per cent of the wives were born less than $25 \mathrm{~km}$ from their husbands' birthplace (see Figure 6.9). They calculate for the different regions that half of the wives came from $28.8 \mathrm{~km}$ from their husband's birthplace. Pagézy and I found that 3 children out of 10 were born on the same trail as their two parents ( 28 per cent); also 3 in 10 were born on a different path (31 per cent), which means that their parents left their group of birth, temporarily or for good. Only 13 per cent were born in the place of their mother (see Table 6.6).

Distances between birthplace and place of residence at the time of the survey were evaluated, both in Ndele by Cavalli - Sforza and
Figure 6.9 Distances between birthplaces of spouses

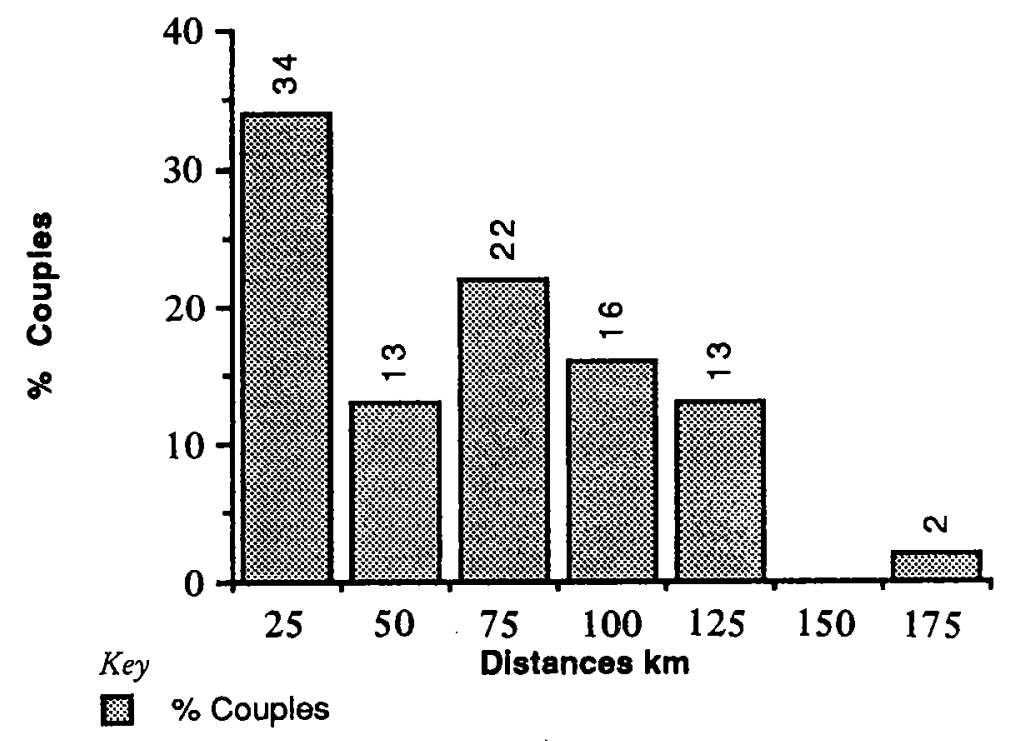

Source: Cavalli-Sforza and Hewlett 1982

Figure 6.10 Distances between birtbplace and residence (Ndele region)

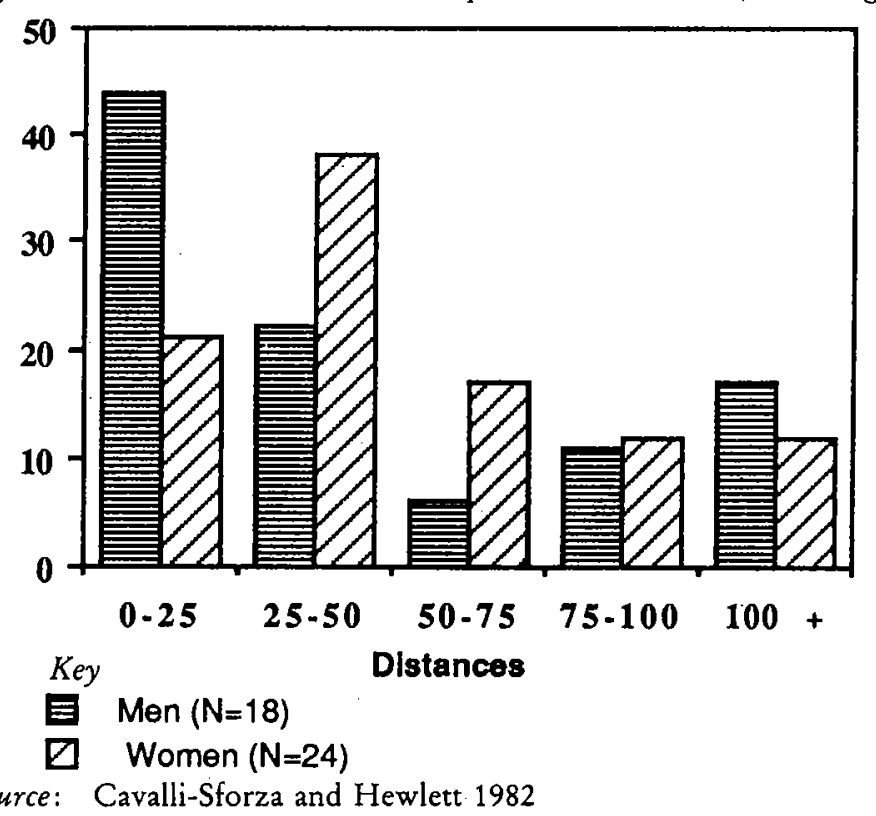


Figure 6.11 Distances between birthplace and residence (BagandouLoko region)

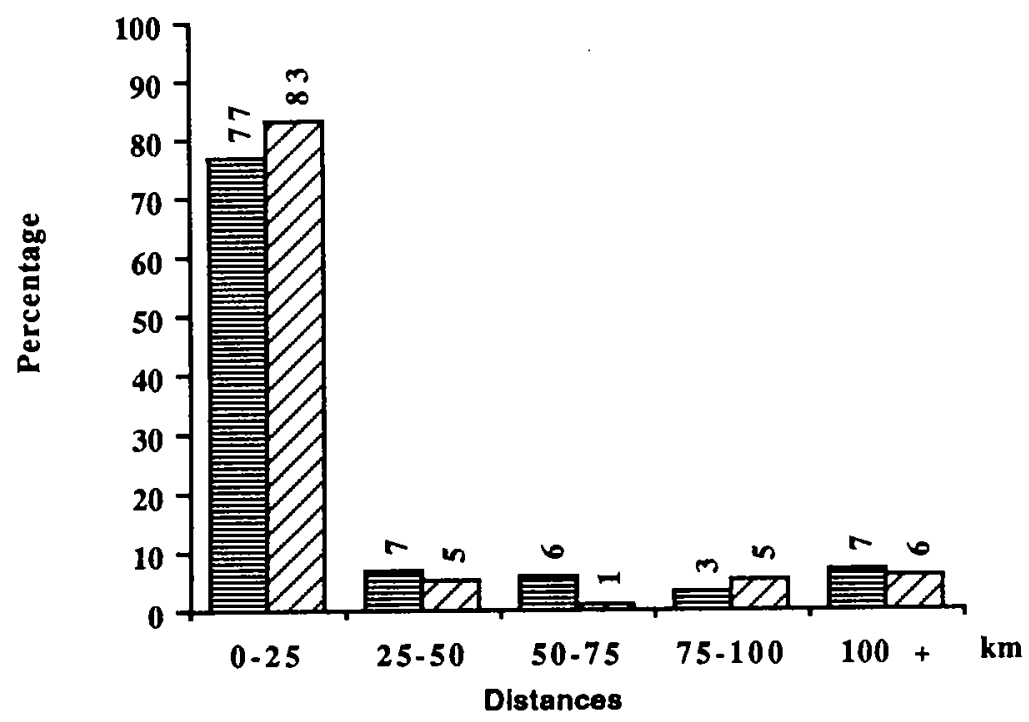

Key 自 Men $(\mathbf{N}=86)$

Women $(\mathrm{N}=\mathbf{8 4})$

Source: Cavalli-Sforza and Hewlett 1982

Hewlett (1982) and in Bagandou by ourselves. Distances are different in the two regions, which is not so surprising because of the differences of population densities, which are much higher in Bagandou than in Ndele. In Ndele, the distance separating birthplace and place of residence is small (less than $50 \mathrm{~km}$ ) but higher for the women than for the men: only 22 per cent of the men, against 38 per cent of the women, were born between 25 and $50 \mathrm{~km}$ away (see Figure 6.10). In the Bagandou region, three-quarters of both men and women live under $25 \mathrm{~km}$ from their birthplace. 48 per cent of the men and 39 per cent of the women still live on their native path, which limits the movements during the lifetime to less than 60 per cent of the cases (see Figure 6.11).

This way the stability of residence of persons in the Lobaye region may be calculated. As shown already, 43 persons out of 100 live where they were born; 69 per cent were born at the same place as one or the other of their parents, therefore 30 persons out of 100 still live where their parents were born. Stability of residence is limited to a third of the individuals, over two generations. This corresponds to the nucleus around which the camps are formed.

We can thus summarise these different levels of social organisation in relation to the spatial organisation:

Table 6.7 Different levels of social organisation in relation to the spatial organisation (Aka Pygmies)

\begin{tabular}{|l|l|}
\hline \multicolumn{1}{|c|}{ SOCIETY } & \multicolumn{1}{|c|}{ SPACE } \\
\hline $\begin{array}{l}\text { ECONOMIC COOPERATION } \\
\text { the family camp }\end{array}$ & Local: TERRITORY \\
the neighbours' camps & $>$ BAND \\
\hline $\begin{array}{l}\text { LONG VISITS } \\
\text { in-laws' camps: affective visits } \\
\text { lineages: social visits (mourning) } \\
\text { or emigration }\end{array}$ & Regional: OTHER TERRITORIES \\
\hline
\end{tabular}

\section{Relationship with the Villagers}

General Pattern Aka Pygmies entertain the same kind of relationship with the different ethnic groups of the Lobaye region, in spite of differences of detail. The general pattern is as follows: every Aka individual is associated, from birth to death, with a villager; previously it was with a lineage of villagers, but nowadays the association is more individualistic. In this region they say 'an Aka belongs to a villager'. That means that the Pygmy has to bring to his 'patron' products of his activities in the forest, mainly meat but also honey and Irvingia nuts, and he has also to help the farmer when needed, in cutting the trees for the new fields, or in tiring work like digging a hole, carrying heavy things or bringing wood. In return the farmer has to take care of 'his' Pygmy, by giving him iron tools, cooking-pots, salt, palm oil, tobacco, even clothes, and allowing him to take from the fields the starchy food he needs, mainly plantains, cassava and taros (cf. Bahuchet 1985, Bahuchet and Thomas 1985). These mainly economic relations also have very long historical roots, and both groups have a place in the mythology of the other (cf. Thomas and Bahuchet 1988).

Trails and Villages The first point is the orientation of the trails as the axis of Aka home-range. All of them start from a village and run 
through the forest. That is the materialisation of the two poles of the Aka way of life: the forest and the village. The same trails are also used by the villagers for their own forest activities; however their territorial system is very different (cf. Thomas 1963).

In the Lobaye region, the ethnic groups (Ngbaka as well as Ngando) present a similar traditional organisation. The villages are inhabited by families whose males are all born in the same patrilineage. However, a child belongs to the lineage where he/she is born, that is to say that the children born during their father's bride service period belong to their mother's lineage. The patrilineage as a whole owns the land; on this area any member of the lineage has rights for hunting, fishing, gathering and farming. In fact members of the community may only gather the products: any conjugal family is allowed to slash some plot of forest, but owns only the cultivated plants of this field. When it is left fallow, any other member of the lineage may, subsequently, open a new field there. Starting from the permanent village long trails extend, which belong to the different patrilineages. All the fields are planted along these lineages' trails, and it is also along these trails that people move for forest activities. The whole community or only the men of a village spend several months each year living in camps in the forest, for gathering caterpillars (September), for fishing (May-June), or for snaring.

We should remember that if the Aka are using the same trail, its meaning for them is very different: it is not in the least the territory of a single lineage, and the Aka lineage itself does not own any territory. According to the rules of social access to territories, possibilities of mobility allow the Aka to use a much larger territory than the farmers, who are limited to their lineage's trail.

The second point concerns the relationship between the Aka and the villagers living on the same trail. The majority of the Aka, mainly all the members of the nuclei of the camps defined before, are associated with the farmers' lineage owning the trail. Herein lies an important, two-fold factor of cohesion: the groups live on the territory of their 'patrons' because they 'belong' to them, and symmetrically the majority of the members of a regional 'band' are associated with the same village.

Who has the Choice? In the village Aka Pygmies find equipment such as iron tools or cooking pots, as well as major food stuffs like salt, oil and starchy food. They also find protection against other villagers, or against misfortune and illness. However the Aka fundamentally have no choice: the relationship is hereditary. The villagers have no greater choice, because they inherit the relationship with the Pygmies from their fathers. There is nevertheless a stage of life when the association with a villager is questioned; this happens when an Aka gets married. The two young persons select each other, and the two families agree on the conditions (e.g. bride-price). The 'patrons' are not involved in these negotiations. A 'patron' may propose a wife to some youth, but he cannot force him to marry her; usually he helps to gather the belongings necessary for the bride-price (which is also a way to strengthen the links with the young man) but he cannot really prevent a marriage of which he disapproves. But after marriage there is another negotiation in the villagers' world: as usually the two young people are associated with two different farmers, the latter have to negotiate in order to decide who will get the relation with the new Pygmy. Will each patron preserve the relation with 'his' Pygmy, or will the patron of one of the partners also take on the other partner? This negotiation is concluded by goods given by the patron who gets the second Aka to the patron who has 'lost' his Aka, and once again, the choice is not the Aka's: the villagers choose which Aka will change association.

The only way for the Aka to manifest their hostility towards their patrons, is through desertion. This may be temporary, in which case the group or the family remains away from the village for more than the normal cycle. That is the easier way to show the patron that, for instance, he is a niggard. If the conflict is more serious, after a fight, the move will be permanent. The camp will then migrate and leave this village and this trail. Any farmer is ready to welcome any Aka. In the case of migration within the same ethnic group, if the former patron learns where 'his' Pygmies are, a negotiation between him and the new patron may take place. Cloarec-Heiss and Thomas (1978: 18) reported such an emigration; after the murder of the elder of the group by the villagers, his sons left the Loko region to reach Mongoumba, $80 \mathrm{~km}$ away. In this case, these Aka even changed the ethnic group, leaving the Ngbaka for the Monzombo.

\section{The Baka of Eastern Cameroon}

The Baka Pygmies, living in the eastern part of Cameroon as well as northeastern Gabon, are less well documented than the Aka. There 
are no modern anthropological data published, and only superficial or partial papers are available (Philippart de Foy 1984, Vallois and Marquer 1976). On the contrary there are good linguistic data, two dictionaries and several volumes of oral literature (Brisson and Boursier 1979, Brisson 1981-84, 1984). I myself made a brief survey in the Baka country in November 1985, prepared by compilation of all the specific vocabulary contained in the dictionaries. I was thus able to state precisely a number of notions and activities, as well as compare Baka subsistence strategies with those of the Aka. Indeed, there is a large amount of common vocabulary in the Aka and Baka languages, in spite of the fact that Aka is a Bantu language and Baka an Oubanguian language (two different families; cf. Bahuchet and Thomas 1986). Baka spatial mobility will be presented here mainly in comparison with that of the Aka, and through their own conception of it, with the vocabulary; unfortunately I cannot furnish any quantitative data.

\section{Social Groups}

The Baka present a social organisation similar to that of the Aka, with the same levels: camp, meeting of neighbouring camps, descent groups, all of these in flux because of the visits.

The basic socio-economic unit is the camp $b \bar{a} l \bar{a}$, the local group consisting of a mean of seven families, i.e. thirty-two individuals (seven males, seven females and eighteen children); the minimum and maximum sizes are two families (sixteen persons) and sixteen families with ninety people (Vallois and Marquer 1976: 113). The camp is constituted around a nucleus of parents, spouses and parents of spouses. Every Baka belongs to a patrilineal descent group, $y \grave{e} \bar{e}$, but the camp includes members of several lineages. A census made by Vallois gives an average of seven different lineages in a local group, three being represented by males and four by females (calculated from data in Vallois and Marquer 1976: 120-1). Members of any given lineage are dispersed throughout the Baka country. Data published by Vallois and Marquer show that 30 per cent of the nublisheen lineages are represented in all three areas studied, and two-thirds in more than one region:

Number of

in one region only in 2 regions in 3 regions

lineages present:
The local groups move along a path, kàjé. However a traveller is asked 'where are you from?', using the term tólo, 'region'. As among the Aka, it seems that several camps move on the same trail. These neighbouring camps have constant relations, and when settled close together, their members visit daily (mòsäsänü is the name of these short visits). Large religious festivals called jéngi are performed while several camps are settled close together: the 'walk to go to dance' is named tōmbi. These ceremonies are the most important part of Baka ritual life, not only because of the affirmation of the cohesion of the community, but also because this is the time of formal initiation of boys.

On many occasions conjugal families move from their own group to visit relatives in other camps. These visits lasting several weeks, or even several months, are named yelè. Thus like the Aka, the Baka practise and distinguish between two types of visits, those with and those without sleeping in the group visited.

\section{Spatial Mobility}

Throughout the year the community is moving and changing composition, maybe even more than among the Aka; indeed the vocabulary for the task groups and the communities seems richer (see Figure 6.12). There are two basic types of communities: the collective camp bälä, and bèsā, the large gathering of several groups settled at the same place. It is the camp bäla which is subdivided according to seasons and activities. Nowadays, because of decreasing mobility, there are two poles, the collective camp in the forest $b \bar{a} \bar{a}$, and a large semi-permanent settlement right near the farmers' village ( $g$ bägàlà).

\section{Task Groups and Seasonality}

Even if the Baka calendar is not well known, we can summarise it as follows. Due to their more southernly location, seasons in the Baka country differ slightly from those of the Aka: a dry season from December to February is followed by increasing rains until a second short dry season in June, July and August, before the maximum of the rains (September and October), and a rapid change in November to the new dry season (see Figure 6.13).

The most seasonal activities are dam fishing, at each change of rainfall twice a year (dry seasons: February and June), gathering 


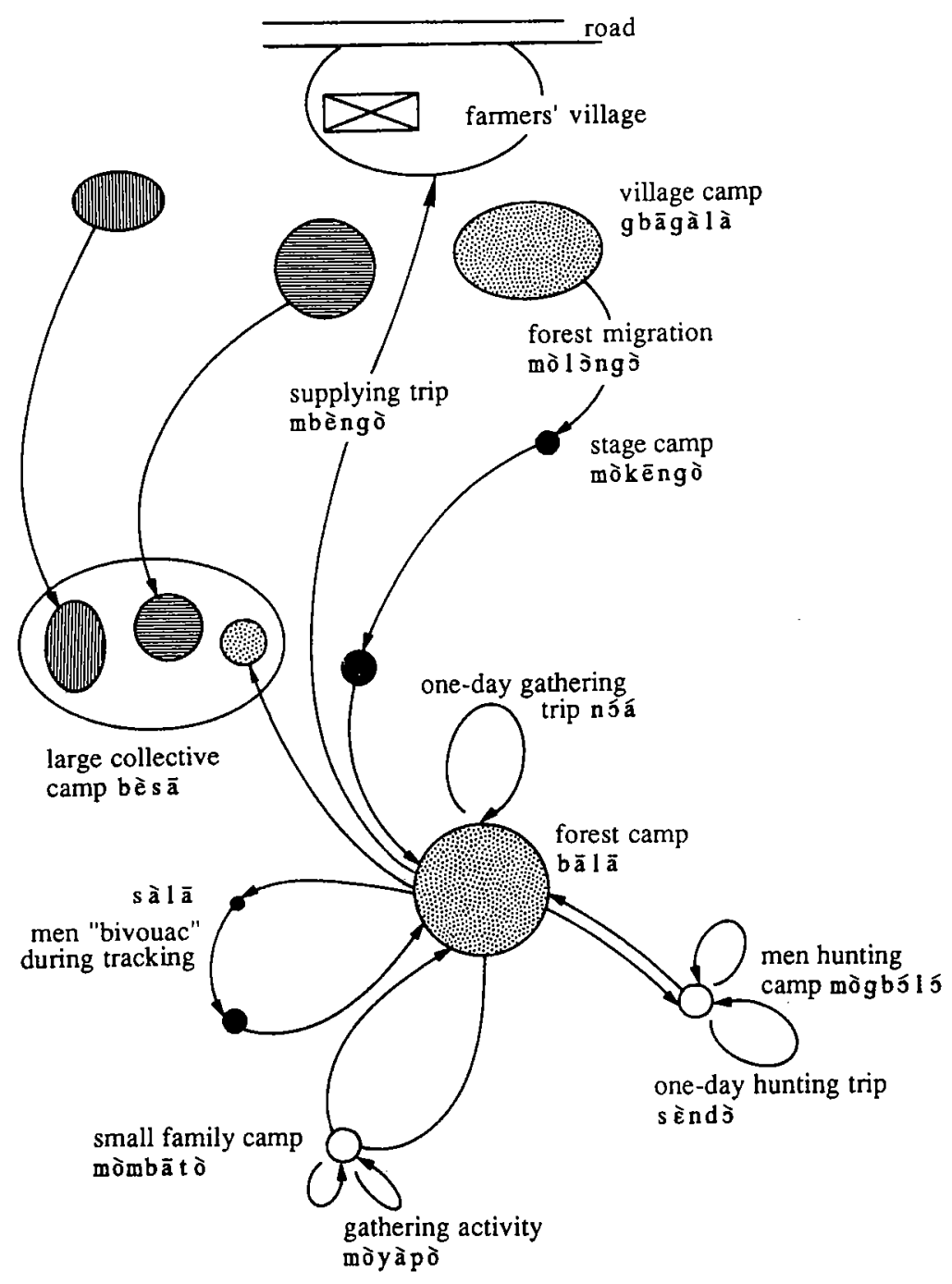

caterpillars (large rainy season: September), gathering the Irvingia nuts twice, at both dry seasons (January-February and June). Honey seems to be mainly collected during the short dry season (June). Gathering and fishing activities may be practised by only a few families, leaving the large group; such smaller camps are named
Figure 6.13 Comparison of rainfall: number of rainy days in the Baka region (Moloundou, Cameroon) and Aka region (Boukoko, C.A.R.)

\section{rainy days}

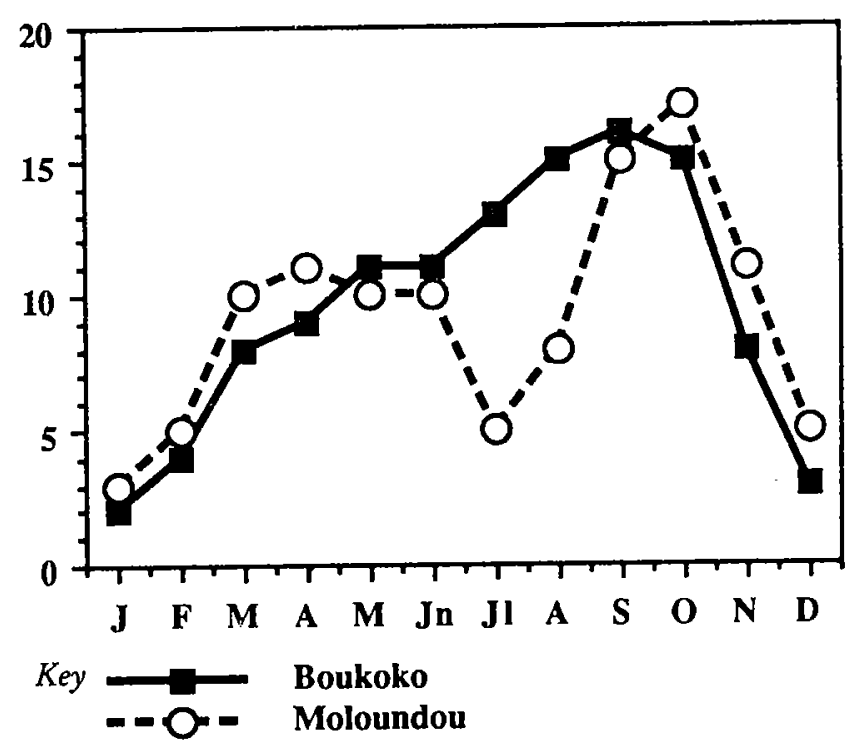

mòmbätò. However dam fishing involves mainly all the women of the whole community.

Seasonality in hunting techniques is not yet very clear; the large dry season seems to be preferred for collective spear hunting, and the rainy season for small spear hunting. The Baka do not use any net for collective hunting, but only spears. They distinguish different group sizes of hunters, and several hunting techniques, according to the duration and the distances: ngbásá a litrle hunt (for porcupines and duikers) with dogs, by one, two or three hunters, sènd’̀ a quasi-individual hunt (mainly for hogs) without dogs, lasting a few hours around the collective campsite, màkā a collective spear hunt involving all the men of the group, settled in a hunting camp for several weeks (without their wives) and lastly a hunting migration mòlìngj, for elephants, involving all the men, without settling a specific hunting camp but only one-night bivouacs. In these last two cases, the type of hunting is named bòpanga, 'tracking'. 
During the hunting performed from males' camps, a young man usually stays back at the camp during the hunt; his only task would be to call at night, in order to guide the hunters back to the camp. Some hunters explain that the fear of getting lost prevents them from settling in unknown areas.

\section{Access to Resources}

The game belongs to the owner of the weapon which kills it. In the case of a collective hunt, it will be shared between the participants. Strangers to the camps, living on the trail, are not allowed either to hunt or to gather in this region. In particular, large fruit trees like Irvingia and Baillonella belong to group members. In the modern co.ttext of increasing sedentarisation for instance, the Baka consider these trees their own, causing conflicts with the lumber companies. However, accessibility to home ranges seems permitted through the patrilineages and marriage. Everybody is welcome in the camps of his kin móbilà, which include members of all the patrilineages of the direct parents (mothers and grandparents), as well as the members of the family-in-law, bògili. This pattern of accessibility to resources is thus similar to that of the Aka.

\section{Baka and Villagers}

It is not known if the trails used by the Baka are also used by the villagers. Nowadays the exchange system between farmers and Baka hunter-gatherers has evolved considerably. Many, if not all, the Baka groups practise some agriculture on their own, thus following neatly the agricultural calendar. They slash the new fields during both dry seasons, and work in the cocoa plantations (of the villagers but sometimes their own) partly in April but mainly in November for the harvesting, in a different place because the crop fields are located near the villages, but the cocoa plantations are usually in the forest, quite far from the villages.

\section{Discussion}

\section{Social and Spatial Mobility}

Similarities Despite the impression of diversity created by controversial publications, which have focused on various aspects of Pygmy society, we may now underline important similarities in the mechanism and organisation of spatial and social mobility and territorial behaviour among the four Pygmy populations, Mbuti, Efe, Aka and Baka, from East to West of the Congo basin.

1. All the groups, despite differences in size, are predominantly patrilocal and virilocal; however always present are a minority of couples who are uxorilocal or matrilocal, thus leading to bilocality.

2. Among all groups, the newborn Pygmy is included in a patrilineal descent group, along with the patrilineages from the maternal side; this patrilineage is the main factor for exogamy.

3. The local group is not simply a patrilineal community; on the contrary it is always constituted by people belonging to several patrilineages; nevertheless one patrilineage counts more members than the others and determines a core or nucleus. On the other hand, the patrilineages are distributed across the whole country, and none of them owns any territory.

4. The composition of the community is animated by a process of temporary fragmentation, dividing in sub-groups which aggregate again.

5. Some families sometimes leave their community, for visiting their affines living in other territories; symmetrically relatives coming from other communities live in this group several times in the year: in this way, the composition of the group is always changing, around the patrilineal nucleus.

6. Through the dispersion of relatives and the relationship between two families through marriage, every Pygmy has right of access to several territories, in addition to his birth-territory.

7. Several neighbouring groups aggregate during some weeks in each annual cycle, supplying this large community with specific collective hunting, and celebrating large festivals.

These are the major similarities I found between the Aka, Baka, Mbuti and Efe Pygmies. It is also interesting to note that nowhere is there a strong correlation between seasons and mobility; food supply is seldom the cause of fission of the community; on the contrary, mobility seems connected with their relationship with the farmers, as we will discuss soon. Moreover all the territories are linear, starting from a farmers' village and spreading out in the forest.

Differences and Constants The major difference between Mbuti, 
Efe and Aka Pygmies, resides in the size of the band. Among both Mbuti and Efe, the basic residential group is large, composed by related people around a patrilineal nucleus; this group is sometimes fragmented into smaller units. This regional group owns a territory, but several neighbouring bands may sometimes join and associate for particular ceremonies, accompanied by specific collective hunting.

In the case of the Aka, the basic group also consists of related people around a nucleus, but it is small, and several groups, only related by few marriages, share the same territory, associating several times to form a large regional band. This pattern looks more like the dyadic bands described by Ichikawa (1978).

Table 6.8 Comparison of Aka and Mbuti group-structure

\begin{tabular}{|l|l|l|}
\hline & \multicolumn{1}{|c|}{$\begin{array}{c}\text { LOCAL GROUP } \\
\text { smaller unit }\end{array}$} & $\begin{array}{c}\text { BAND } \\
\text { larger unit }\end{array}$ \\
\hline AKA & Patrilineal nucleus & Aggregate of different nuclei \\
\hline MBUTI & Division of the band & Patrilineal nucleus \\
\hline
\end{tabular}

It was shown that among the Mbuti, the major function of the flux is the resolution of conflicts (Turnbull 1968:137); it seems that among other groups like the Baka, disputes are not solved by dispersion of divisions of the group, but by other means, mainly religious (Dodd 1980). Nevertheless, these differences underline the importance of the process as a whole.

The constants are: the existence of a patrilineal nucleus, the succession of fragmentation and aggregation of groups in larger units coinciding with ritual ceremonies, the location of the larger unit (or band) on a particular home-range (a territory), and the change in the composition of the band by means of visits, allowing families to live outside their own territory. The gathering of groups corresponding to the larger units are the occasion of the large collective festivals involving the participation of all (with the predominance of polyphonic music) in ritual ceremonies of prime importance devoted to the regeneration of the community (Bahuchet and Thomas 1987). These ceremonies, named jengi
(Baka), mokondi (Aka) or molimo (Mbuti) underline quite well the social function of the fragmentation process.

All these Pygmy groups present a territorial organisation, since each local group is living on limited area, on which other groups may live only with permission of the former. However, we have seen that Pygmy territorial organisation is accompanied by important social mechanisms which result in a minimisation of territoriality, leaving the primacy to cooperation and mutual aid. The similarities between these Pygmy groups concern the mechanisms; the differences concern only minor modalities. Of prime importance therefore is the social function of spatial mobility, a mechanism which seems to be adopted by the various Pygmy societies according to the specificity of their environment, i.e. the 'ecological constraints'.

The Aggregation Model The majority of these characteristics fits well with what was described among other groups of hunting and gathering societies. Describing in the Eskimo society the alternance of a large group phase ('public life') and a small group phase ('private life'), Mauss and Beuchat, as early as 1904, noted that 'social life does not persist at the same level all the year round, but goes through successive and regular stages of increasing and decreasing intensity, a succession of rest and activity, spending and mending' (author's transl.). Lee threw new light on this model, which 'visualises group size as a continuum along the dimension of concentration-dispersion. Any specific group size postulated in this framework is likely to be an ephemeral event in the continual reshaping of groups into larger and smaller aggregates' (1972: 184).

In the case of the Pygmies as for many other societies, the aggregation of camps is a social opportunity for large collective festivals necessary for community cohesion: we may thus say that their spatial mobility is due to social reasons. It is nowadays clear that the 'double morphology' or better the fusion and fission process is more due to the necessity for every human society to reproduce, ${ }^{4}$ than due to ecological adaptation as was assumed in the beginning of hunter-gatherer research (cf. Steward 1955).

\section{Pygmies and Villagers}

The way of life of the Pygmies cannot be understood without the villagers, their non-Pygmy neighbours. This relationship may very briefly be summarised as that between two economic systems, each 
Table 6.9 The Pygmy-Villager system

\begin{tabular}{|c|c|c|}
\hline & PYGMIES (P). & VILLAGERS (V) \\
\hline implements & $\begin{array}{l}\text { coming from } V \\
\text { belonging to } P\end{array}$ & themselves \\
\hline work products & for $P$ producers & for $V$ producers \\
\hline exchange & $\begin{array}{l}\text { decided by } \mathrm{V} \\
\text { counterpart fixed } \\
\text { by V }\end{array}$ & $\begin{array}{l}\text { counterpart and } \\
\text { decision } V\end{array}$ \\
\hline schedule & $\begin{array}{l}\text { P choice, } \\
\text { V pressure }\end{array}$ & $V$ choice \\
\hline home range & often identical to $\mathrm{V}$ & $\mathrm{V}$ territory \\
\hline mobility & free, $P$ pattern & free, $V$ pattern \\
\hline $\begin{array}{l}\text { home and social } \\
\text { group }\end{array}$ & P choice & V choice \\
\hline religion & P choice & V choice \\
\hline politics & $\begin{array}{l}\text { P organization } \\
\text { V pressure }\end{array}$ & $\mathrm{V}$ organization \\
\hline
\end{tabular}

with their own production and consumption patterns, but with interaction at the distribution level (Table 6.9, after Bahuchet 1985: 550).

Spatially, we have already seen that the home range used by the Pygmies is closely connected with the villages. In every case, one extremity of the territory reaches the village. At least in the case of the Aka, the axis of the Pygmy home-range is shared with the villagers: the path along which the Aka band moves is at the same time the territory of specific farmers' patrilineages. In the same way, the village influences the mobility of the Pygmies, as a kind of magnet. They come to the village to obtain iron tools, salt and cultivated starchy food, against products of the forest like meat, honey or nuts; they come also to help the villagers in their agriculture. Thus the Pygmies adapt their calendar in order to be near the villages at the key seasons of the agricultural cycle.

If we turn towards the other side of the association, it is noteworthy that the products obtained from the Pygmies always play a role in very important distribution networks, as observed among the Aka's neighbours (Bahuchet and Thomas 1985): the supply of game is necessary to hold the very large meetings following mourning, during which the alliances between the groups is maintained.

Pygmies in the Village Social System The coexistence of the Pygmies with the villagers has to be evaluated in terms of ecology, economy and social organisation. Ecology: the farmers also extract forest resources, as they themselves hunt and trap, and to some extent gather; they often share the same home range as the Pygmies. Economy: both societies rely upon the food supplied by the other. Social Organisation: both societies are constructed in such a way that the products of the interrelationship enter into the heart of their networks. I do not know if the forest cannot be inhabited without agriculture, as my American colleagues think (cf. Bailey et al. 1989), but I do know that the complementary association between two specialised societies is so efficient that it has imposed itself, for a very long time (since 'the beginning'?), as shown by oral traditions, the mythology and the linguistic development of all Pygmy groups (cf. Bahuchet and Thomas 1986, Thomas and Bahuchet 1988). It was proposed by Bird-David (1988) that 'the hunter-gatherers' relationship with non hunter-gatherers' should be understood 'in terms of role-relationship within the hunter-gatherers' 'social system'. In the case of the Pygmies, it seems better to consider exactly the reverse proposition: the Pygmies are part of the social system of the villagers, which is evident through the participation of the Pygmies in all the prime rituals of the villagers, like mourning, or reciprocal initiations (cf. Bahuchet and Thomas 1985: 28, Bahuchet and Guillaume 1982).

Considering the ambiguity of the way of life of the Pygmies, and of their relationship with the villagers, it is striking to notice the similarities with other types of societies, mainly the peripatetics According to Rao (1985: 98), peripatetics are nomadic people, 
without control on the food resources they need and that they obtain from others, against goods and services. In the Pygmy case, we are faced with people who do not produce all that they eat. There is a large gap between their activities, typically hunting and gathering, and their diet which is hard to distinguish from that of the farmers. Although fully hunters and gatherers, however, half of their diet is provided by cultivated plants. Pygmies are only partly food producing, and a large proportion of their diet is not produced by themselves. Looking towards the social status of peripatetics, we again find similarities with the Pygmies, first of all social marginality, mainly expressed in restrictions on inter-marriage. Peripatetics are despised by their host societies, yet feared (Rao 1987: 10), as are the Pygmies by their farmers. Several of the complementary oppositions between peripatetics and their host societies, as summarised by Rao (1987: 10) are identical with those existing between the Pygmies and their farmers as given in Bahuchet and Guillaume (1982): wild/tame, Nature/Culture, disorder/order, power/authority, anomy/lawfulness. Rao (1987: 7) has already asked whether the Mbuti should "be classified as "commercial hunters and gatherers" or as peripatetics who also hunt and gather?' Bollig (1987) showed convincingly that in several cases in Africa, it would be better to consider hunter-gatherers and peripatetics in terms of continua rather than oppositions. Hunter-gatherers are in many reported cases able to live more by renting their labour, which can be interpreted as a flexible adaptation to their social environment. This view is even more true while considering the trend of development of the way of life of the Pygmies in central Africa.

Contemporary Change Nowadays, the majority of the Pygmies have changed their traditional life-styles. Some of them have begun to plant gardens; others leave the forest for salaried work in lumber companies or coffee plantations. Many of them have broken the traditional and exclusive relationship with a particular villager, preferring to work for the highest bidder. In the majority of cases, the Pygmies now tend to settle for longer periods near the villages, however while still spending several months living in the distant forest, gathering and hunting, usually for trading purposes. Even Pygmies working for companies, or already cultivating, spent these months in the forest. Development projects always stumble over the persistence of the two poles, which is also a problem for the schooling of children. The Pygmies often neglect their little gardens, which can seldom feed the family, and they prefer to rely upon the food supply from the farmers, selling their services for all kind of chores.

These realities are wrongly interpreted in the development programme, and should be taken into account in a true concern for the promotion of these impoverished Pygmy hunter-gatherers.

\section{Notes}

1. All the classical papers about Pygmies consider the forest as basically uniform, in temporal and spatial terms, with resources uniformly available anywhere and at any time (cf. Bicchieri 1979, Turnbull 1968). These considerations are wrong and are due to a fundamental misunderstanding of forest ecology.

2. Turnbull cites several causes of disputes, concerning food (54 per cent), theft ( 4 per cent) and territory ( 3 per cent), but also communal life (sex 30 per cent, relationship with the village 9 per cent); (1965: chapter 11).

3. I published the reconstructed calendar elsewhere (Bahuchet 1986: 8-11) but it has been recently criticised by Headland (1987: 480) saying that such a calendar 'is not based on empirical data, but is a description of how they assume they lived "at the end of the nineteenth century"'. To my mind, and I presume for many ethnographers, what the people say is empirical data. The fact that a given way of life is impossible to observe nowadays does not mean that it never existed. Should this be the case we would have to burn the major part of the ethnological libraries.

4. 'Contrary to the other social animals, human beings do not content themselves with living together, they produce society for living' (Godelier 1984: 9; transl. by me).

\section{Autbor's Note}

I would like to thank the editors of this volume for their help in transforming the first 'Franco-English' draft of this chapter into a more comprehensible English text. 


\section{References}

Abruzzi, W.S., 1979, 'Population pressure and subsistence strategies among the Mbuti Pygmies.' Human Ecology 7, 183-9

Bahuchet, S., 1978, 'Les contraintes écologiques en forêt tropicale humide: l'exemple des Pygmées Aka de la Lobaye (Centrafrique).' Joumal Agriculture Traditionnelle Botanique Appliquée XXV (4), 257-85

$\longrightarrow, 1979$, 'Utilisation de l'espace forestier par les Pygmées Aka, chasseurscueilleurs d'Afrique centrale.' Social Sciences Information 18 (6), 9991019

- 1985, Les Pygmées Aka et la forêt centrafricaine, etbnologie écologique. Paris: SELAF, 'Ethnosciences 1'

1986, 'Linéaments d'une histoire humaine de la forêt du bassin congolais', in Vertébrés et forêts tropicales bumides d'Afrique et d'Amérique. Mémoires du Mus. Nat. Hist. Nat., Série A Zoologie, Tome 132, $297-315$

_ 1988, 'Food supply uncertainty among the Aka Pygmies (Lobaye, C.A.R.)', in I. de Garine and G. Harrison (eds) Coping with Uncertainty in Food Supply, 118-49. Oxford: Clarendon Press

1990, 'Food sharing among the Pygmies of Central Africa'. Kyoto: African Study monographs 11(1), 27-53

$\longrightarrow$, and H. Guillaume, 1982, 'Aka-farmer relations in the northwest Congo basin', in R.B. Lee and E. Leacock (eds) Politics and History in Band Societies, 189-211. Cambridge/Paris: Cambridge University Press/ Maison des Sciences de l'Homme

$\longrightarrow$, and J.M.C. Thomas, 1985, 'Conservation des ressources alimentaires en forêt tropicale humide: chasseurs-cueilleurs et proto-agriculteurs d'Afrique Centrale', in Les Techniques de conservation des grains à long terme 3(1), 15-31. Paris: Editions du CNRS

$\longrightarrow$, 1986, 'Linguistique et histoire des Pygmées de l'ouest du bassin congolais.' Sprache und Geschichte in Afrika 7(2), 73-103

- 1987, 'Pygmy religions', in M. Eliade (ed.) The Encyclopedia of Religion New York: Macmillan, 12: 107-10

Bailey, R.C. and N.R. Peacock, 1988, 'Efe Pygmies of northeast Zaïre: subsistence strategies in the Ituri forest', in I. de Garine and G. Harrison (eds) Coping with Uncertainty in Food Supply, 88-117. Oxford: Clarendon Press

Bailey, R.C. et al., 1989, 'Hunting and gathering in tropical rain forest: is it possible?' American Antbropologist, 91(1), 59-82

Bicchieri, M.G., 1969, 'A cultural ecological comparative study of three African foraging societies', in D. Damas (ed.) Contributions to Antbropology: Band Societies. Ottawa: Nat. Museum of Canada Bulletin 228, 172-83

Bird-David, N.H., 1988, 'Hunter-gatherers and other people: a reexamination', in T. Ingold, D. Riches and J. Woodburn (eds) Hunters and Gatberers 1: History, evolution and social change, 17-30. Oxford: Berg

Bollig, M., 1987, 'Ethnic relations and spatial mobility in Africa: a review of the peripatetic niche', in A. Rao (ed.) The Other Nomads, 179-228. Cologne: Böhlau Verlag

Brisson, R., 1981-84, Contes des Pygmées Baka du Sud-Cameroun: vol. 1 et 2, Histoires et contes d'enfants; vol. 3 et 4, Contes des anciens. Douala: BP 5351

, 1984, Lexique Français-Baka. Douala: BP 5351

Brisson, R, and D. Boursier, 1979, Petit dictionnaire Baka-Français. Douala: B.P. 1855

Cashdan, E., 1983, 'Territoriality among human foragers: ecological models and an application to four Bushman groups.' Current Anthropology 24(1), 47-66

Cavalli-Sforza, L.L. and B. Hewlett, 1982, 'Exploration and mating range in African Pygmies.' Ann. Human Genetics 46, 257-70

Cloarec-Heiss, F. and J.M.C. Thomas, 1978, L'Aka, langue bantoue des Pygmées de Mongoumba; introduction à l'étude linguistique, phonologie. Paris: SELAF

Dodd, R., 1980, 'Ritual and the maintenance of internal co-operation among the Baka hunters and gatherers.' Paper presented at $2 n d$ Int. Conf. Hun. Gath. Societies (Quebec)

Eibl-Eibesfeld, 1., 1972, Ethologie, biologie du comportement. Paris: N.E.B. Godelier, M., 1984, L'Idéel et le matériel; pensée, économies, sociétés. Paris: Fayard

Hallé, F., R.A.A. Oldeman and P.B. Tomlinson, 1978, Tropical Trees and Forests, an Architectural Analysis. Berlin: Springer Verlag

Harako, R., 1976, 'The Mbuti as hunters: a study of ecological anthropology.' Kyoto University African Studies X, 37-99

b. 1981, 'The cultural ecology of hunting behavior among the Mbuti Pygmies in the Ituri forest, Zaire', in R. Harding and G. Teleki (eds) Omnivorous Primates, 499-555. New York: Columbia University Press

Harris, D., 1969, 'Agricultural systems, ecosystems and the origins of agriculture', in P.J. Ucko and G.W. Dimbleby (eds) The Domestication and Exploitation of Plants and Animals, 3-15. London: Duckworth

Hart, J.A., 1978, 'From subsistence to market: a case study of the Mbuti net hunters.' Human Ecology 6(3), 325-53

Hart, T.B. and J.A. Hart, 1986, 'The ecological basis of hunter-gatherer subsistence in African rain forests: the Mbuti of eastern Zaire.' Human Ecology 14(1), 29-55

Headland, T., 1987, 'The wild yam question: how well could independent hunter-gatherers live in tropical rainforest ecosystems?' Human Ecology 15(4), 463-91

Helm, J., 1968, 'The nature of Dogrib socio-territorial groups', in R.B. Lee and I. DeVore (eds) Man the Hunter, 118-25. Chicago: Aldine 
Hewlett, B., J.M.H. van de Koppel and L.L. Cavalli-Sforza, 1982, 'Exploration ranges of Aka Pygmies of the Central African Republic.' Man $17,418-30$

Hladik, A., 1978, 'Phenology of leaf production in rain forest of Gabon: distribution, and composition of food for folivores', in G.G. Montgomery (ed.), The Ecology of Arboreal Folivores, 51-71. Washington: Smithsonian Institution

_ 1982, 'Dynamique d'une forêt équatoriale africaine: mesures en temps réel et comparaison du potentiel de croissance des différentes espèces.' Acta Oecologica (Oecologia Generalis) 3 (3), 373--92

Hladik, C.M., 1981, 'Diet and the evolution of feeding strategies among forest primates', in R. Harding and G. Teleki (eds) Omnivorous primates', 215-54. New York: Columbia University Press

Ichikawa, M., 1978, 'The residential groups of the Mbuti Pygmies.' Osaka: Senri Etbnological Studies 1 'Africa 1', 131-88

_ 1981, 'Ecological and sociological importance of honey to the Mbuti , Tet hunters, eastern Zaire.' Kyoto: African Study Monographs 1, 55-68

Jewell, P.A., 1966, 'The concept of home range in Mammals', in P. Jewel and C. Loizos (eds) 'Play, exploration and territory in Mammals', Symp. Zool Soc. London 18, 85-109

Kelly, R.L., 1983, 'Hunter-gatherer mobility strategies.' J. Antbr. Research $39(3), 277-306$

Leacock, E.P., 1954, "The Montagnais "hunting territories" and the fur trade.' Am. Antbr. Ass. Memoir vol. 56, no. 5

Lee, R.B., 1972, 'Work effort, group structure and land-use in contemporary hunter-gatherers', in P. Ucko (ed.) Man, Settlement and Urbanism 177-85. London: Duckworth

Letouzey, R., 1985, Carte phytogéographique du Cameroun, et Notices Domaines de la forêt dense humide: 63-142). Toulouse: Institut de la (Domaines de la forêt dense humide: 63-142). Toulouse:

Mauss, M. and H. Beuchat, 1904 (1966), 'Essai sur les variations saisonnières des sociétés eskimos: étude de morphologie sociale.' (L'Année Sociologique, 1905), in Sociologie et Anthropologie, 389-477. Paris: P.U.F.

Milton, K., 1985, 'Ecological foundations for subsistence strategies among the Mbuti Pygmies.' Human Ecology 13 (1), 71-8

Oldeman, R.A.A., 1974, 'L'architecture de la forêt guyanaise.' Paris: Mémoires ORSTOM no. 73

Philippart de Foy, G., 1984, Les Pygmées d'Afrique Centrale. Roquevaire: Editions Parenthèses

Rao, A., 1985, 'Des nomades méconnus: pour une typologie des communautés péripatétiques.' L'Homme XXV (3), 97-120

(ed) 1987, The Other Nomads Peripatetics minorities in crosscultural perspective. Cologne: Böhlau Verlag
Schebesta, P., 1952, Les Pygmées du Congo Belge. Brussels: Mémoires de l'Institut Royal Colonial Belge XXVI, no. 2

Steward, J., 1955, Theory of Culture Change: the methodology of multilinear evolution. Urbana: University of Illinois Press

Tanno, T., 1976, 'The Mbuti net-hunters in the Ituri forest, eastern Zaire: their hunting activities and band composition.' Kyoto University African Studies X, 101-35

Terashima, H., 1983, 'Mota and other hunting activities of the Mbuti archers.' African Study Monographs 3, 71-85

,- 1985 , 'Variation and composition principles of the residence group (band) of the Mbuti Pygmies.' African Study Monographs Suppl. 4, 103-20

Thomas, J.M.C., 1963, Les Ngbaka de la Lobaye. Le dépeuplement rural chez une population forestière de la République Centrafricaine. Paris: Mouton

Thomas, J.M.C.T. and S. Bahuchet, 1988, 'La littérature orale pour l'histoire de l'Afrique centrale forestière', in W. Möhlig, H. Jungraithmayr and $\mathrm{F}$. Thiel (eds), Die Oralliteratur in Afrika als Quelle zur Erforschung der traditionellen Kulturen 'Collectanea Instituti Anthropos 36', 301-27. Berlin: D. Reimar Verlag

Turnbull, C.M., 1965, Wayward Servants; the two worlds of the African Pygmies. New York: The Natural History Press

, 1968, 'The importance of flux in two hunting societies', in R.B. Lee and I. De Vore (eds) Man the Hunter 132-37. Chicago: Aldine

- 1983, The Mbuti Pygmies; change and adaptation. New York: Holt, Rinehart and Winston

Vallois, H.V. and P. Marquer, 1976, Les Pygmées Baka du Cameroun: anthropologie et ethnographie. Paris: Mémoires du Mus. Nat. Hist. Nat., Série A Tome C

White, F., 1983, The Vegetation of Africa and Map of the Vegetation of Africa. UNESCO/AETFAT

Wiessner, P., 1977, 'Hxaro: a regional system of reciprocity for reducing risk among the IKung San.' Ann Arbor: PhD diss. University of Michigan

Wilmsen, E.N., 1973, 'Interaction, spacing behavior and the organization of hunting bands.' J. Anthropological Research 29 (1), 1-31

Winterhalder, B. and E.A. Smith (eds), 1981, Hunter-gatherer Foraging Strategies, Ethnographic and Archeological Analyses. Chicago: University of Chicago Press

Yellen, J.E. and R.B. Lee, 1976, 'The Dobe-/Du/da environment: background to a hunting and gathering way of life', in R.B. Lee and I DeVore (eds) Kalabari Hunter-gatherers, 27-46. Cambridge, Mass: Harvard University Press 